\title{
Studying Contemporary Chinese Law: Limits, Possibilities and Strategy
}

\section{INTRODUCTION}

Studying contemporary Chinese law may deepen insight into Chinese society, despite the crushing of the democracy movement in June, 1989 and of the hopes for political reform that it symbolized. During the 1980s - a decade of reform - China's leadership promoted the development of formal legal institutions intended to shape newly-reformed activities of the Chinese economy and the Chinese state. Despite the fate of the democracy movement those institutions have remained in place. The links between legal institutions and reform suggest the importance of studying them in order to better understand relations between state and society in post-revolutionary China. The institutions created during the decade of reform marked, notably - at least in theory - departures not only from the Cultural Revolution but from thirty years of well-established prior practice: Chinese legal institutions had been either largely neglected or politicized by the end of the 1950s, long before they were swept aside during the Cultural Revolution. Given the novelty of the institutions created or revived during the $1980 \mathrm{~s}$, it is no wonder that their development has been limited, hesitant and uncertain. The new institutions are stamped by influences flowing from traditional Chinese social structure and values; by a tangle of values and institutions created by the Chinese revolution itself; and by the still more confused swirl of politics, institutions and values in the post-totalitarian aftermath that began in the late 1970s and will continue for a very long time. Legal development has been further critically hindered by the lack of consensus among the Chinese leadership on China's future economic and political development.

Stanley Lubman is Partner and Head, China Practice Group, Thelen, Marrin, Johnson \& Bridges, San Francisco. This article grew out of a paper originally presented at a conference on American Studies of China organized by the Woodrow Wilson International Center for Scholars at the Wye Plantation in 1988. The author is grateful for support provided by the Law Schools of Harvard and Stanford, where he revised the article while in residence as Visiting Professor in the spring semesters of 1989 and 1990, respectively, and by the law firm of Thelen, Marrin, Johnson \& Bridges. Judith M. Lubman, William P. Alford and James V. Feinerman were kind enough to read and comment on earlier drafts. 
What can the study of Chinese law bring to the study of China itself? This Article first distills what we have learned. It reviews Chinese legal studies since their revival in the 1960s in the United States, where foreign studies of modern Chinese law has been most vigorous since the People's Republic of China ("PRC") was established. The major themes that emerged from research before the reform decade emphasized the politicization of law, the persistence of traditional cultural influences and the impact of bureaucratic practice on current institutions - all themes which remain important today. Since the advent of reform, the most notable studies of Chinese law have explored the extent to which emergent legal institutions protect and legitimate economic transactions, the activities of new or revived dispute settlement mechanisms, and the appearance of nascent conceptions of legal rights; meanwhile, ominously, the criminal process remains highly politicized.

The article then turns to methodological problems in the study of Chinese law. Much of what has been published on Chinese law in recent years, particularly in American law reviews, has amounted to little more than cataloging recent developments and explicating texts. Major obstacles to study are created by the object of study itself: China does not yet have a legal system; the continued relationship between law and politics remains obvious; law is often treated formalistically. Values derived from a Chinese culture that is itself in the course of change continue to shape both the outlines and activities of institutions, but are difficult to identify clearly in practice. Meanwhile, China itself remains closed to the student of law in practice.

Foreign observers create additional difficulties by not being selfconscious enough about their own theoretical assumptions. Both extreme cultural relativism and insistence on intellectual categories derived from Western legal systems have threatened to skew study, with the latter trend more evident in recent years. The conclusion suggests that both the problems inherent in the subject-matter and in the foreign students' methodology may be more manageable in a research strategy that would aim at searching for institutional functions while widening the study of Chinese law to include Chinese legal culture.

\section{American Legal Studies of China Before Reform}

After the PRC was established, studies of Chinese law, like Chinese studies generally, languished amidst the Sino-American hostility of the 1950s. For three decades developments within China further discouraged studies of Chinese law. Well before the beginning of the Cultural Revolution, law had already become merely one 
voice in a chorus of institutions that were expected only to echo Chinese Communist Party ("CCP") policy. The anti-rightist movement of 1957-1958 and the Great Leap Forward in 1959-1960 undid most of whatever prior progress had been made toward the regularized operation of Chinese legal institutions. ${ }^{1}$ Later, during the Cultural Revolution, formal legal institutions were condemned as "bourgeois" and legal personnel purged. 2 Law schools were closed, their faculties dispersed, and they were the last institutions of higher-level education to be reopened after the end of the Cultural Revolution.

The state of Sino-American relations and the flux of Chinese politics hardly encouraged the study of Chinese law in China or elsewhere. Nevertheless, Chinese legal studies in the United States developed vigorously. This section summarizes the beginning of those studies and the research which they generated. ${ }^{3}$

\section{A. The Establishment of Chinese Legal Studies}

Although a handful of scholars had already begun to study Chinese law and policies toward law, ${ }^{4}$ Chinese legal studies in the United States were greatly enlivened in the early 1960s, when foundation grants were given to support the training of a small group of scholars who became the first professors of Chinese law at a small number of American law schools. By the early 1970s, four such scholars were engaged in teaching and research on the legal institutions of the PRC: Jerome A. Cohen (Harvard), Victor H. Li (Michigan, later Columbia and Stanford), R. Randle Edwards (Columbia), and myself (University of California-Berkeley). Courses on modern Chinese law were by then also being offered at a number of other law schools.

For over fifteen years the center of Chinese legal studies was Harvard, where Cohen established the East Asian Legal Studies Program. During Cohen's stay, Harvard graduated a significant

1. See, e.g., Shao-Chuan Leng, Justice in Communist China: A Survey of the Judicial System of the Chinese People's Republic 57-63 (1967).

2. For a summary, see, e.g., Shao-Chuain Leng and Hungdah Chiu, Criminal Justice in Post-Mao China 17-20 (1985).

3. A detailed discussion of the state of Western studies of Chinese law after World War II and the beginning of the revival of Chinese legal studies in the United States is Cohen, "Introduction," in Contemporary Chinese Law: Research Problems and Perspectives 1 (Jerome A. Cohen ed. 1970).

4. See, e.g., Buxbaum, "Preliminary Trends in the Development of the Legal Institutions of Communist China and the Nature of the Criminal Law," 11 Int l \& Comp. L. Quart. 1 (1962); Michael, "The Role of Law in Traditional, Nationalist and Communist China," China Quart., Jan.-Mar. 1962 at 124; Shao-Chuan Leng, Justice in Communist China: A Survey of the Judicial System of the Chinese Peoples Republic (1967); Hsia and Murray, "Communist Chinese Legal Development Reflected in the Country's Legal Publications," 25 Quart. J. Lib. of Cong. 290 (1968); Hsiao, "The Role of Contracts in Communist China," 53 Calif L. Rev. 1029 (1964). 
number of students who went on to specialize on China as practicing lawyers or scholars.5 The program flourished until he left Harvard in 1979, and it continued to be an important center for teaching and research on Chinese law.

The politicization of Chinese law throughout the 1960s and most of the 1970s stunted the growth of Chinese legal studies during the latter decade, although one scholar, William Jones, joined the ranks of professors teaching and doing research on Chinese law and legal history. ${ }^{6}$ After 1972 , when new possibilities appeared for combining interests in China with law practice in the newly-revived U.S.-China trade, most of the outstanding young law graduates of the 1970s with backgrounds in Chinese studies chose to enter practice rather than to teach or do research on Chinese law. ${ }^{7}$ I left full-time law teaching to enter practice in 1972, and, at least until the Tiananmen events of June, 1989, practice continued to attract law graduates who were also Chinese specialists, leaving but a few to engage in scholarly study of Chinese law as law professors. ${ }^{8}$

\section{B. Pre-Reform Scholarship}

Before reform, scholarship was conducted using only sparse and elusive materials for research. For many years the Chinese-lan-

5. Without pretending to completeness, I cite the following alumni of the Harvard East Asian Legal Studies Program, who have written widely and promoted the study of Chinese law as law teachers or practitioners: R. Randle Edwards, currently teaching Chinese law at Columbia Law School; William P. Alford, who after teaching Chinese law at UCLA returned to Harvard in 1989 (see n. 42 infra); James V. Feinerman, currently teaching Chinese law at Georgetown Law School; Victor H. $\mathrm{Li}$, who taught Chinese law at Stanford before becoming President of the East-West Center; Michael Moser, partner at Baker \& McKenzie, Hong Kong; Preston Torbert, partner at Baker \& McKenzie, Chicago; Jamie Horsley, formerly partner at Paul, Weiss, Rifkind, Wharton \& Garrison; Timothy Gelatt, associate at Paul, Weiss, Rifkind, Wharton \&c Garrison; Donald Clarke, currently teaching Chinese law at the University of Washington Law School after teaching at the School of Oriental and African Studies of the University of London for five years; and Alison E.L. Conner, currently teaching Chinese law at Hong Kong University.

6. See, e.g., Jones, "Studying Ching Law: The Ta Ching Lu Li," $22 \mathrm{Am} . J$. ,Comp. L. 330 (1974); Jones, "An Approach to Chinese Law," 4 Rev. Soc. L. 3 (1978).

7. Alford and Feinerman, supra n. 5, are two law school graduates of the 1970s who went into practice after graduation and then became professors specializing in Chinese law. Until the late 1980s, law practice was understandably more attractive than teaching to some. The China lawyers are stimulated by the challenges of living and working in China and trying to bring about economically constructive results in the face of the complexities and frustrations that China presents to them and to their clients. Home offices had other more practical difficulties, and the end of the decade saw a perceptible decline in the numbers and interest of American law firms in China.

8. Among scholarly practicing lawyers are Michael Moser, who received a Ph.D. in anthropology before graduating from the Harvard Law School, see Michael J. Moser, Law and Social Change in a Chinese Community: A Case Study From Rural Taiwan (1982), and Preston Torbert, who earned a Ph.D. in Chinese history at Chicago in addition to a law degree at Harvard. 
guage core of a foreign specialist's Chinese law library was limited to incomplete collections of statutes published between 1950 and 1966, a few law textbooks from the 1950s and a few legal journals, of which one ceased publication in 1966 and the other was only published for two years. ${ }^{9}$ Chinese newspapers and non-legal journals were essential sources, although they were often difficult to obtain except in a small number of libraries. Some scholars supplemented documentary sources, such as newspaper clippings, with émigré interviews in Hong Kong, like American social scientists who studied the operation of the Chinese apparatus of control at the basic level.10

Using these scant resources, research was carried out vigorously both on domestic institutions and legal aspects of China's international behavior. When domestic legal institutions were submerged in the confusion and disorder of the Cultural Revolution, American scholars turned some of their attention during the 1970s to studies of Chinese attitudes toward international law and legal aspects of China's foreign trade. ${ }^{11}$ The more enduring work, however, was devoted to domestic Chinese legal institutions.

\section{The Institutions Studied}

\section{a. Control and Sanctioning}

The most compelling subjects of study were the formal and informal institutions involved with sanctioning, ${ }^{12}$ which were particularly visible throughout the 1950 s and 1960s. Their prominence

9. The legal literature from the PRC known (but not necessarily available) in the 1960s is summarized in Hsia, "Chinese Legal Publications: An Appraisal," in Cohen, supra n. 3 at 20.

10. See, e.g., Ezra F. Vogel, Canton Under Communism (1970) and A. Doak Barnett, Cadres, Political Power and Bureaucracy in Communist China (1967). A contemporary account of refugee interviewing in legal research is Cohen, "Interviewing Chinese Refugees: Indispensable Aid to Legal Research on China," in Cohen, supra n. 3 at 84 .

11. See, e.g., Jerome A. Cohen and Hungdah Chiu, People's China and International Law (1974); Law and Politics in China's Foreign Trade (Victor H. Li ed. 1976).

12. See, e.g., Buxbaum, supra n. 4; S.C. Leng, supra n: 4; Jerome A. Cohen, The Chinese Criminal Process (1968); Cohen, "The Chinese Communist Party and 'Judicial Independence' 1949-1959," 82 Harv. L Rev. 867 (1969); Cohen, "Reflections on the Criminal Process in China," $68 \mathrm{~J}$. Crim. L. \& Criminology 68 (1977); Ginsburgs and Stahnke, "The Genesis of the People's Procuratorate in Communist China, 19491951," China Quart., Oct.-Dec. 1964 at 1; "The People's Procuratorate in Communist China: The Period of Maturation, 1951-1954," China Quart, Oct-Dec. 1965 at 53; "The People's Procuratorate in Communist China: The Institution Ascendant, 19541957," China Quart., Apr.-June 1968 at 82; Li, "The Evolution and Development of the Chinese Legal System," in China: Management of a Revolutionary Society 221 (John M. H. Lindbeck ed. 1971); Li, "The Public Security Bureau and Political-Legal Work in Hui-yang Hsien [Kwangtung], 1952-1964," in The City in Communist China 51 (John W. Lewis ed. 1971); Lubman, "Form and Function in the Chinese Criminal Process," 69 Colum. L. Rev. 535 (1969); Pfeffer, "Crime and Punishment: China and the United States," in Cohen, supra n. 3 at 261. 
reflected the CCP's preoccupation with consolidating control over Chinese society and eliminating political opposition and "enemy" economic classes. Emigré interviewing in Hong Kong helped overcome China's inaccessibility to foreign students, provided important detail to help foreign scholars reconstruct the bureaucracies that conducted and oversaw sanctioning, and suggested that the apparatus of the Chinese party-state had penetrated Chinese society deeper than any previous Chinese bureaucracy.

\section{b. Civil Law and Dispute Settlement}

Other branches of law withered in China during the first 25 years after Liberation. Most private law simply became irrelevant after land, financial institutions and most commercial and industrial enterprises were collectivized. Policy toward law resisted not only codification but regularization in the operation of legal and other bureaucratic institutions, with the exception of brief intervals during the 1950 s and the early 1960 s.

Some post-1949 legislation dealt spottily with such family law matters as marriage, divorce and inheritance, which were little studied by lawyers in the United States although they were given some attention by legal scholars elsewhere. ${ }^{13}$ In the management of the economy administrative, legal and political institutions were intermingled ${ }^{14}$ and legal relations between enterprises largely regulated by administrative orders; legal aspects of inter-enterprise relations were not a promising subject of study. ${ }^{15}$

A Chinese practice of particular interest was the use of mediation to handle minor civil disputes and disturbances of public order. Preference for informal dispute settlement had marked Chinese society long before 1949; the CCP also emphasized the importance of mediation, although supposedly the traditional practice was transformed into a new and politicized version operating in the context of the complex control apparatus that penetrated Chinese society down to every urban street. The study of mediation in the PRC embodies a challenge that runs throughout the study of modern China,

13. See, e.g., Marinus J. Meijer, Marriage Law and Policy in the People's Republic (1971).

14. See, e.g., Pfeffer, "The Institution of Contracts in the Chinese People's Republic," China Quart., Apr.-June 1963 at 153 and China Quart., July-Sept. 1963 at 115; Lubman, "Methodological Problems in Studying Chinese Communist Civil Law," in Cohen supra n. 3 at 230.

15. Lubman, id. In the Soviet Union, state-controlled industry had given birth to a new branch of the law dealing with contracts between state-owned enterprises and the settlement of disputes arising out of them. See, e.g., John Hazard, Communists and Their Law (1969). Theoretical interest in China in following Soviet industrial organization in a manner that could have led to such legal development became anathema in mid-1957. 
that of attempting to identify continuities or breaks with traditional institutions. ${ }^{16}$

\section{Salient Themes}

\section{a. Cultural Influences on Contemporary Institutions and Policies Toward Law}

Scholars of Chinese law, like their counterparts in other disciplines, have sought to understand Chinese Communist policies and practice in relation to Chinese history. ${ }^{17}$ In traditional Chinese philosophy two schools opposed each other, contrasting Confucian morality and rites $(l i)$ and the competing Legalist school's insistence on punishments $(f a)$ as the preferred means for ordering society. ${ }^{18}$ The reflection of these contrasts were found by some scholars in simultaneous contemporary Chinese emphases on both the need to require offenders to cultivate "correct" ways of thinking and to punish them harshly. ${ }^{19}$

The emphasis on supposed continuities between CCP policies toward law and traditional concepts of social control was largely based on abstract generalizations about institutions that could only be studied across a frustrating distance, and about whose operation little detailed knowledge could be gleaned at the time. Sometimes insistence on continuities forced unruly modern facts into a theoretical mold; thus, what some scholars characterized as modern totalitarianism was seen by others as the use of group pressure and building of community consensus. In addition, focusing on purely Chinese con-

16. See, e.g., Cohen, "Chinese Mediation on the Eve of Modernization," 54 Calif. L. Rev. 1201 (1966); and Cohen, "Drafting People's Mediation Rules for China's Cities," in Lewis, supra n. 12 at 29; Lubman, "Mao and Mediation: Politics and Dispute Resolution in Communist China," 55 Calif. L. Rev. 1284 (1967).

17. Chinese legal history was largely neglected at American law schools with the notable exceptions of Pennsylvania and Harvard. At Pennsylvania, Derk Bodde and Clarence Morris collaborated to make available an invaluable source of information about Ch'ing law, Derk Bodde and Clarence Morris, Law in Imperial China (1967). Published as Studies in East Asian Law at Harvard were Patricia E. Griffin, The Chinese Communist Treatment of Counter-Revolutionaries, 1924-1949 (1976); The T'ang Code: Volume I, General Principles (Wallace Johnson, translator, 1979); and Paul Heng-Ch'ao Chen, Chinese Legal Tradition Under the Mongols (1979). A conference organized by the East Asian Legal Studies Program at Harvard led to the publication of Essays on China's Legal Tradition (Jerome A. Cohen, R. Randle Edwards and Fumei Chang Chen eds. 1980).

18. See, e.g., Schwartz, "On Attitudes Toward Law in China," in Government Under Law and the Individual (Milton Katz ed. 1957) reprinted in Cohen, The Chinese Criminal Process, supra n. 12 at 62; Li, "The Role of Law in Communist China," China Quart., Oct.-Dec. 1970 at 66.

19. See, e.g., Leng, supra n. 1; Victor H. Li, Law Without Lawyers (1978) at 2431 , and $L i$, supra $n .18$. 
cepts such as $l i$ and $f a$ impeded attempts to relate the modernization of Chinese law to similar processes in other developing nations.

Not all scholars of the 1960s and 1970s found latter-day echoes of Confucianism and Legalism; it was possible to find structural continuities that did not turn on philosophy, as in the use of a "semiofficial substructure" to augment the formal criminal process in both traditional and contemporary China. ${ }^{20}$ In studying civil dispute-settlement it seemed to me then that mediation was neither wholly traditional nor wholly Communist, and performed recognizable functions derived from both styles; we needed to differentiate among specific continuities and discontinuities. ${ }^{21}$

\section{b. Politicization: Chinese and Soviet Influences}

Influences that shaped the subservience of law to politics even before the Cultural Revolution were sought in the Chinese use of Soviet models, paralleling a dominant theme in research by American social scientists at the time.22 Although much attention was given to describing borrowed Soviet institutions, insights were also gained into the ways the models were often followed mechanically and formalistically and often modified or misunderstood.23 For example, the use of Soviet-type police, procuracy and courts as elements of the criminal process was formalistic at best, skewed by the anti-bureaucratic thrust of Maoist ideology and frequently disrupted by political campaigns throughout the 1950 s and $1960 \mathrm{~s}^{24}$

Not all politicization was ascribed to Soviet influence. The experience acquired by the CCP while it ruled large areas of China

20. Cohen, "Reflections on the Criminal Process in China," $68 \mathrm{~J}$. Crim. $L$ \& Criminology 323 at 349 (1977).

21. Lubman, supra n. 16 at 21 . The cited article rejected the discovery or rejection en bloc of $l i$ or $f a$ in contemporary China. It suggested that the functions intended for the contemporary institutions by their Communist creators were being deformed in practice by tenacious traditional cultural values. It did not, however, speculate on how long the tensions between traditional and new values would continue and how the tensions might eventually be resolved. I recognize that emphasis on function itself raises methodological issues. See the discussion infra at 1139-1141.

22. See, e.g., Oksenberg, "Bibliographical Essay; Politics Takes Command: An Essay on the Study of Post-1949 China," in The Cambridge History of China Volume 14. The People's Republic, Part I: The Emergence of Revolutionary China 1949-1965, (Roderick MacFarquhar and John K. Fairbank eds. 1987) 543 at 579: "The Sino-Soviet alliance and the extensive Soviet presence in China further encouraged analysts to stress the Soviet-like qualities of the new regime: the adherence of its leaders to Marxism-Leninism, the totalitarian grip of the top political leaders upon the entire society and culture, and the centrally planned economy in which resources were allocated through political command."

23. Scholarly opinion was not unanimous. Emphasizing the importance of the model see, e.g., Cohen, supra n. 12 at 11 , while emphasizing the extent to which that model was deviated from or skewed, see, e.g., Lubman, supra n. 12 at 537, n. 2 at 547548.

24. See, e.g., Lubman, supra n. 12. 
before 1949 led some students to emphasize the decisive influence of that experience on post-1949 policies toward law. The infusion of the Maoist "mass line" into legal and paralegal institutions before the PRC was established was closely studied by a few, particularly Leng Shao-chuan, who emphasized the politicization of dispute settlement, the denigration of formal institutions, and the use of legal forms to dramatize CCP policies. ${ }^{25}$ :

\section{The Continued Relevance of Pre-Reform Research}

The early studies summarized above were largely descriptive, which is understandable enough in view of the undeveloped nature of the subject matter and the frustrating inaccessibility of the PRC to Americans at the time. Although only limited theoretical generalizations emerged, the subjects studied and the principal themes explored in the previous research remain very relevant. The origins and background of contemporary institutions, illuminated by the earlier research, continue to influence the operation of legal institutions today.

For example, both the formalism and the mobilizational disruptions that marked Chinese legal institutions during the 1950s have persisted in more recent legal institution-building. Even more fundamentally, the earlier research, which highlighted the politicization of law during the first thirty years of the PRC, remains essential to comprehending the Chinese leadership's continued intention to make law serve politics. The day-to-day operation of the criminal process, for example, has remained as responsive to signals from the leadership as it was in the 1950s, even if the signals are no longer called "campaigns."26

Today's Chinese criminal process, furthermore, cannot be understood without recalling that the activities of the agencies charged with administering the formal criminal process - police, procuracy, and courts - were shaped by a variety of competing approaches toward bureaucracy and organization ${ }^{27}$ and that since 1949 the criminal process has been dominated by the police ${ }^{28}$ This is but an

25. See Leng, supra n. 1 at 1-26. See also "Judicial Work in Taihang District," 6 China L. and Government 6 (Stanley Lubman ed., No. 3, 1973), a translation of T'aiHang qu sifa gongcuo gaikuang (Report on the General Situation in Judicial Work in T'ai Hang District,) a report on legal work in an area occupied by the Chinese Communist Party during the mid-1940s.

26. See, e.g., Note, "Concepts of Law in the Chinese Anti-Crime Campaign," 98 Harv. L. Rev. 189 (1985).

27. See, e.g., Cohen, supra n. 12 at 18-50, emphasizing the complexity of the formal sanctioning bureaucracy, its competing concerns for reliability and efficiency, and the discretion of officials throughout the system; Lubman, supra $n .12$ at 566-68, contrasting competition between a mobilizational and politicized model of the criminal process and a routinized alternative; Pfeffer, supra n. 12 at 261 .

28. Amazingly, some of today's students write about the Chinese criminal pro- 
example that suggests that we will understand today's Chinese legal institutions more deeply if we recall how the Chinese, supposedly "learning from elder brother," departed extensively from the Soviet model under the influence of Chinese experience and Chinese circumstances.

To gain perspective on the tentativeness of Chinese law-making, it is necessary to recall the style of Chinese law-making during the 1950s. The earlier research, particularly in its analysis of formallegal institutions for social control, also underscores the limits on the vision of today's Chinese leaders when they contemplate possible future forms of legal institutions and the polity in which they might exist. Finally, without understanding how the tenacious roots of earlier decades shape today's institutions, it has been all too easy for many foreign observers to exaggerate the distance between current and previous practice.

\section{American Legal Studies of China Since 1979}

\section{A. Reform and Chinese Legal Development: Overview}

The most notable feature of legal institution-building since 1978 at the instance of the Chinese leadership is their interest, to some extent, in creating and using meaningful legal institutions. By contrast to pre-reform practice, many laws have been intended not only to express new policies but to shape, to some extent, the conduct of economic actors in their relationships with each other and with agencies of the state. ${ }^{29}$

Since 1979 codification has been pursued. Reflecting considerable research and preliminary drafting conducted intermittently since the late 1950s, Codes of Criminal Law and Criminal Procedure were promulgated in 1979, the first China has known since the abrogation of the Nationalist Codes in 1949.30 Law-making has not been confined to criminal law; throughout the 1980s an extraordinary explosion of laws and regulations reflected the Chinesé leadership's intention to recast much of the structure of the Chinese economy and the Chinese state. The professionalization of the law was also begun, even if modestly. Most Chinese law schools reopened in 1979

cess as if recent history is irrelevant. See, e.g., Herb, "Economic Crime in the People's Republic of China," 12 ILSA J. Int $l L .55,83$ (1989)("By instituting the 'rule of law' as a policy and recreating a formal legal system, [China] has assembled a mechanism to formally deal with economic crimes.")

29. But caution is necessary in this regard because many regulations continue to have a distinctly programmatic tone. Moreover, compl:ance in practice by officials or economic actors with new laws promulgated in Beijing or locally is always a matter for speculation.

30. See, Cohen, Gelatt, and Li, translators, "The Criminal Law in the People's Republic of China," 73 J. Crim L. \& Criminology 136 (1982). 
and began to graduate students in 1983 , and both a bar and legal scholarship have emerged, albeit hesitantly. ${ }^{31}$ New laws and regulations have given expression to basic changes that reform policies have begun to make in the organization and institutions of the Chinese economy. ${ }^{32}$ Thus, new rural communes have been dismantled as units of production and a "production responsibility" system instituted that enlarges the discretion of 185 million peasant families to decide what they grow; new commercial entities have been created in the countryside by transforming communes and the production organizations subordinate to them into township and village enterprises; vigorous collective enterprises have been created; in industry, the autonomy of state-owned enterprises has grown somewhat, and first steps have been taken toward developing a company law as well as new institutions such as stock ownership and enterprise bankruptcy; some small state enterprises have been privatized through sale or lease; domestic joint ventures have been created; and private enterprises have been created. All of the changes mentioned above and many others in the areas of banking, finance, insurance and industrial property, have been the subject of extensive legislative activity.

With reform, the relationships among economic actors have been addressed by laws on contractual and non-contractual responsibility, both in a partial codification of civil law and in other laws and regulations. This growing body of law is being applied with increasing frequency by newly revived courts along with other revived institutions such as notaries and lawyers, and by new arbitration commissions charged with settling contract disputes. Every sector of the Chinese economy and virtually every major part of the apparatus of the Chinese state has felt the impact of this law-making activity, ${ }^{33}$ although practice has been uncertain and tied to policy.

31. On legal education at the beginning of the decade of reform, see Gelatt and Snyder, "Legal Education in China: Training for a New Era," 1 China L. Rep. 44 (1980). A more recent article is Kraus, "Legal Education in the People's Republic of China," 13 Suffolk Transnat $l$ L. J. 75 (1989) which, though sometimes overoptimistic ("China has embraced the need to produce more lawyers. . .while recognizing that a stronger judiciary and growth in the role of law are beneficial aspects of its more liberal internal policies," id. at 132) is informative both about curriculum and student attitudes. See Hom, "Legal Education in the People's Republic of China: A Select Bibliography of English-Language Materials," 6 China L. Rep. 73 (1989).

32. A concise survey of doctrinal issues in the economic and civil law fields is Dicks, "The Chinese Legal System: Reforms in the Balance," China Quart., Sept 1989 at 540, 556-560.

33. See, generally, two articles summarizing some of the accomplishments of Chinese legal reform during 1979-1989: Hsia and Zeldin, "Recent Legal Developments in the People's Republic of China," 28 Harv. Int I J. L. 249 (1987), is a descriptive general summary of developments in most significant legal areas; Lichtenstein, "Legal Implications of China's Economic Reforms," 1 Foreign Investment L. J. 289 (1986), discusses in greater detail legal aspects of domestic economic reform since 
In addition to extensively using legal institutions since 1979 to define economic actors and their relationships to each other, new law-making has extended beyond the economy. A potentially emergent field may be administrative law. The Constitution of 1982 states that "citizens who have suffered losses through infringement of their civil rights by any state organ or functionary have the right to compensation in accordance with law."34 Many Chinese laws and regulations specifically provide for the right of persons affected by decisions of administrative agencies to appeal to local people's courts, ${ }^{35}$ and during the early 1980s a modest experiment was made in using administrative chambers in some local courts to hear cases brought by citizens complaining about alleged arbitrariness of administrative officials.

Serious interest in giving life to this novel institution was expressed in high places. After Party Secretary Zhao Ziyang called for the creation of an administrative law in his report to the Party Congress in October 1987, a draft law on administrative procedure was published in late 1988. A revised draft was adopted by the National People's Congress in March 1989 as the "Administrative Procedure Law"36 which went into effect in December 1989.37 In addition, preliminary consideration also was begun of a statute providing for compensation to private citizens for injuries caused by government agencies. The effectiveness of a nascent Chinese administrative law that purports to allow recourse to the courts by citizens protesting acts of state agencies is obviously limited: the state bureaucracy is controlled by the CCP, whose officials cannot be held accountable under the new law because the Party is not a "state agency" that can be sued under the statute. Yet the new law reflects the existence of strong support within the Chinese leadership for institutions that could foster bureaucratic responsibility. In a political climate different from post-Tiananmen repression, application of the law could be

1979. See also Sidel, "Recent and Noteworthy Legal Works Published in China," $1 \mathrm{~J}$. Chin. L. 251 (1987).

34. Constitution of the People's Republic of China, Adopted on Dec. 4, 1982, by the Fifth National People's Congress of the People's Republic of China at its Fifth Session, Art. 41, in China Lawos for China Business, para. 4-500.

35. Regulations of the People's Republic of China on Administrative Penalties for Public Security, effective January 1, 1987, Laws of the People's Republic of China, 1983-1986 271 (1987).

36. "Administrative Procedure Law Adopted," translated in Foreign Broadcast Information Service, Daily Report: China (hereinafter FBIS, Daily Report: China), 4 April 1989, 19; "Administrative Procedural Law Text," in FBIS, Daily Report: China, 2 May 1989, 92.

37. See, e.g., "Circular Implements Administrative Procedure Law," FBIS, Daily Report: China, 24 Jan 1990, 12; "Yao Yilin on Administrative Procedures Law," FBIS, Daily Report: China, 4 Sept. 1990, 32; "Law Gives the People Power to Sue Officials," China Daily, September 28, 1990. 
used to limit the official arbitrariness that plagues China today. ${ }^{38}$

With reform, Chinese interest in foreign law has grown. Hundreds of Chinese have come to the United States to study law and their studies have helped to stimulate Chinese interest in foreign law. ${ }^{39}$ Many foreign lawyers and legal scholars, including students of Chinese law, have traveled to China to lecture and consult with their Chinese counterparts.

During the 1980s, the scope of research grew as the domain of institutions characterized as "legal" in the PRC expanded. Institution-building has been reflected in the promulgation of laws and regulations, the publication of many scholarly and popular Chinese books and journals and the publication of articles on legal topies in the general press. ${ }^{40}$ The Chinese economic reforms, the policy of "opening" to foreign technology and capital, and the legal explosion that has been briefly summarized here have combined to stimulate American studies of Chinese law, both at American law schools and by practicing lawyers. These studies are discussed below.

\section{B. The Renewal of Chinese Legal Studies}

The remarkable growth of Chinese legal institutions in the context of economic reforms has stimulated Chinese legal studies at numerous U.S. law schools, the most active of which are Columbia ${ }^{41}$, Harvard $^{42}$, Georgetown ${ }^{43}$ and U.C.L.A.44 Specialists are also cur-

38. See generally, Finder, "Like Throwing an Egg Against A Stone? Administrative Litigation in the People's Republic of China," 3 J. Chin L. 1 (1989).

39. Since 1982, the Committee for Chinese Legal Educational Exchanges with China ("CLEEC"), funded by generous grants from the Ford Foundation, the Henry Luce Foundation, the Chinn Ho Foundation, the United States Information Agency, and private individuals, has been supporting study by Chinese law professors and graduate students in the United States and research and lecturing by Americans in China. CLEEC has also co-sponsored with the State Education Commission and the Ministry of Justice one-month sessions on American law that have been conducted in China by American law professors each summer since 1984. Considerable financial support has also been given to this program in some years by the United States Information Agency. Substantial interest seems to exist in China in organizing teaching by Americans in China about American law for longer periods of time and on a more permanent basis.

40. See, e.g., Chinese Law: A Bibliography of Selected English-Language Materials (Constance A. Johnson, compiler, 1990).

41. Columbia's Center for Chinese Legal Studies (which under the direction of Professor R. Randle Edwards has attracted considerable numbers of American law students and visiting Chinese legal scholars alike), houses the Journal of Chinese Law, and serves as the administrative center for CLEEC.

42. In 1989, William P. Alford, an alumnus of the Harvard Law School and its East Asian Legal Studies Program, became Henry L. Stimson Professor of Law and Director of the Program. Prior to his return, courses on Chinese law had been taught each year by a succession of visitors, including, in recent years, Alford, Jerome A. Cohen, James V. Feinerman, Timothy Gelatt, Liu Chu (Department of Treaties and Law, Ministry of Foreign Economic Relations and Trade), Dong Shizhong (Dean, Fudan Law Faculty), and myself. The East Asian Legal Studies 
rently teaching on Chinese law at the University of Washington (Seattle), ${ }^{45}$ the University of California (Berkeley), ${ }^{46}$ the University of Southern California, ${ }^{47}$ Duke $^{48}$ and Washington University at St. Louis ${ }^{49}$. Although the number of professors of Chinese law in U.S. law schools has increased over the previous decade and interest is growing, many law schools still lack courses on Chinese law and many schools at universities with strong Asian programs do not have regular offerings on Chinese law or Chinese legal history. This state of affairs reflects the relatively low state of comparative and foreign legal studies at most American law schools; more professors may be teaching about Chinese law than about Japanese or Soviet law. ${ }^{50}$ Outside the United States, specialists are teaching and doing research at the School of Oriental and African Studies in London,51 the University of Hong Kong, ${ }^{52}$ the University of British Columbia, ${ }^{53}$ the Max Planck Institut fuer auslaendisches und internationalen Privatrecht in Hamburg, ${ }^{54}$ the Academica Sinica in Taiwan, ${ }^{55}$

Program houses visiting scholars and sponsors and maintains an extensive program of speakers.

43. James V. Feinerman teaches courses on Chinese law and is Editor-in-Chief of the China Law Reporter.

44. Visitors have been teaching on teaching on Chinese law since the departure of William Alford.

45. Donald Clarke teaches courses on Chinese law after having been preceded by a number of lecturers and visitors.

46. Robert Berring teaches courses on Chinese law.

47. Hugh Scogin teaches courses on Chinese law.

48. Jonathan Ocko teaches courses on Chinese law and Chinese legal history.

49. William C. Jones teaches courses on Chinese law.

50. The prospects are limited for the growth of research at American law schools and even more limited for evolution of an interdisciplinary approach that I have urged below as the most imaginative. Practicing lawyers will continue to study Chinese laws and regulations as they directly affect foreign trade and investment, and if practice becomes more complex and accessible these lawyers might produce research that links doctrine and practice in an increasingly nuanced fashion. The law schools, because Chinese law as well as other comparative and foreign subjects are such step-children of the curriculum, can only provide limited bases for broadranging research. Special attention by the foundations may be warranted in order to foster research on Chinese law in areas outside those of trade and investment.

51. Michael Palmer, Philip Baker, Anthony R. Dicks and Yuan Cheng are currently teaching in the program leading to a Master's degree. Dicks is a practicing barrister in Hong Kong who wrote "A Legal Opinion" for the monthly China Trade Report from April 1981 to March 1984. An excellent overview of Chinese law reform is Dicks, supra n. 32.

52. Alison Conner and Edward Epstein are teaching courses on Chinese law. Recent publications include Epstein, "Tortious Liability for Defective Products in the People's Republic of China," 2 J. Chin L. 285 (1988); Epstein and Ye Lin, "Individual Enterprise in Contemporary Urban China: A Legal Analysis of Status and Regulation," 21 Int l Lawyer 397 (1987); Epstein, "The Evolution of China's General Principles of Civil Law," 34 Am. J. Comp. L. 705 (1986). Byron Weng, "Some Key Aspects of the 1982 Draft Constitution of the PRC," China Quart, Sept. 1982 at 192.

53. Pittman Potter teaches courses on Chinese law.

54. See, e.g., Muenzel, "Chinese Thoughts on the Heritability of Law: A Translation," $6 R$. Soc. L. 275 (1980); "Die neue Zivilprozessordnung der Volksrepublik 
Tokyo University, ${ }^{56}$ and Waseda University. ${ }^{57}$

By the end of the $1980 \mathrm{~s}$, although legal institutions were still emerging and research was in an early stage, specialists and non-specialists alike had already produced a considerable body of literature about the effects of reform on Chinese law. That literature, selectively reviewed below, suggests both limits and possibilities in the study of Chinese law.

\section{Institutions Studied}

\section{Legal Aspects of Foreign Trade and Investment}

The onset of Sino-American detente and resumption of SinoAmerican trade in 1972 aroused the interest of many American lawyers in Chinese law. Until 1979, however, China's international trade offered relatively few legal aspects for study. Although Sinoforeign trade grew during the 1970s, China's trade continued to be conducted by a centralized Soviet-style bureaucracy in the legal vacuum that had characterized it since the 1950s. Most of China's trade was based on skimpy form contracts that referred to no legal rules at all. Disputes arising out of trade transactions were settled by negotiation and compromise rather than by recourse to procedures for third-party dispute settlement. ${ }^{58}$ Before the 1980s, American legal studies of China's foreign trade were for the most part necessarily confined to ascertaining and explaining Chinese contractual practice. ${ }^{59}$

During the decade of reform, legal institutions emerged where none had existed before in the areas of foreign trade and foreign di-

China von 1982," 47 Rabelszeitschrift fuer auslaendisches und internationalen Privatrecht 78 (1983); "Kartellrecht in China," 33 Recht der internationalen Wirtschaft 261-79 (1987); "Neue Regeln zur Investitionsfoerderung in China," 32 Recht der internationalen Wirtschaft 945 (1986).

55. At the Institute of History and Philology Chang Weren, also a Professor at the Law School of Taiwan University, is one of the leading scholars of Chinese legal history. See, e.g., Chang, "Law Enforcement and Judicial Procedure in China Under the Ch'ing (1644-1911)," thesis submitted to the Committee on Graduate Studies of the Harvard Law School in partial fulfillment of the requirements for the degree of Doctor of Juridical Science, Harvard University, February 1988; Chang, "Traditional Concepts and Present Legal System," 17 National Taiwan Univ. L. J. 1 (1987).

56. Paul H.C. Chen, who earned his J.S.D. at Harvard, is Professor of Law.

57. Professor Hikota Koguchi specializes in Chinese law.

58. Even in negotiations for imports of major capital goods or technology, Chinese negotiators often still resist the use of all but minimal documentation. Sometimes in such contracts foreign sellers with strong bargaining power succeeded in including clauses providing for arbitration of disputes by the Arbitration Commission of the Stockholm Chamber of Commerce, but not until the mid-1980s were any Sino-foreign trade disputes brought to that forum for arbitration.

59. See, e.g., Hsiao, "Communist China's Foreign Trade Contracts and Means of Settling Disputes," 23 Vand. L. R. 503 (1969); Lubman, "Trade Between the United States and the People's Republic of China: Practice, Policy \& Law," L. \& Policy in Int? Bus. 1 (1976). 
rect investment. ${ }^{60} \mathrm{~A}$ considerable body of literature has been produced by practitioners, notably lawyers specializing in Chinese matters at the small number of U.S. law firms that have emerged as the principal specialists in transactions involving the PRC. These include two lawyers trained in the $1960 \mathrm{~s}$, Jerome Cohen ${ }^{61}$ and myself, ${ }^{62}$ joined by a growing number of younger lawyers who have combined a background in Chinese studies with their professional interests. Among those who have been particularly productive are Michael Moser, ${ }^{63}$ Jamie Horsley, ${ }^{64}$ and Timothy Gelatt; ${ }^{65}$ they and other practitioners are often represented in a growing number of collections of essays on trade and investment in the PRC. ${ }^{66}$

60. Sometimes legal development in these areas has diverted attention away from others that do not seem to concern foreigners directly. Actually, enterprises established in China with foreign direct investment, as Chinese legal persons, are subject to the entire body of Chinese law. New Chinese laws on trade and investment are usually translated into English within the PRC and abroad faster than other laws. A useful collection of Chinese laws in translation is China Laws for Foreign Business (CCH Australia Limited, 1985-1988).

61. See, e.g., Cohen, "Negotiating Complex Contracts with China," in Bussiness Transactions with China, Japan, and South Korea (Parviz Saney and Hans Smit eds. 1983); Cohen, "Equity Joint Ventures: Twenty Potential Pitfalls That Every Company Should Know About," China Bus. R., July-Aug. 1985 at 52; Cohen, "The Role of Arbitration in Economic Co-operation with China," in Foreign Trade, Investment and the Law in the People's Republic of China 508 (Michael J. Moser ed., 2d ed. 1987); Cohen and Valentine, "Foreign Direct Investments in the People's Republic of China: Progress, Problems and Proposals," 1 J. Chin. L. 161 (1987); Cohen, "Sex, Chinese Law and the Foreigner," 18 H.K.L.J. 102 (1988).

62. See, e.g., Lubman, "Contracts, Practice and Law in Trade With China: Some Observations," in Chinese Economy Post-Mao, Volume 1: Policy and Performance, A Compendium of Papers Submitted to the Joint Economic Committee, Congress of the United States 764 (November 1978); Lubman, "Foreign Investment in China: Selected Legal Problems and Some Perspectives on Them," in Saney and Smit, supra n. 61 at 4-1; Lubman "Technology Transfer to China: Policies, Law and Practice," in Moser, supra n. 61 at 170; Lubman, "Equity Joint Ventures in China: New Legal Framework, Continuing Questiions," in 2 China's Economy Looks Toward the Year 2000, Selected Papers Submitted to the Joint Economic Committee of the United States 432 (May 21, 1986); Lubman and Wajnowski, "Technology Transfer to the People's Republic of China: Law, Practice and Policy." in Doing Business in China 3-1 (William P. Streng and Allen D. WIlcox, eds. 1990); Lubman, "Investment and Export Contracts in the People's Republic of China: Perspectives on Evolving Patterns," 1988 Brig. Young L. R. 543.

63. See, e.g., Pow and Moser, "Law and Investment in China's Special Investment Areas," and Moser, "Legal Aspects of Offshore Oil and Gas Exploration and Development in China," in Moser, supra n. 61 at 270.

64. See, e.g., Horsley, "The Regulation of China's Foreign Trade," in Moser, supra n. 61 at 5; Horsley, "China. Issues Regulations to Implement Foreign Investment Encouragement Provisions," E. Asian Executive Reports, Jan. 12, 1987 at 7; Horsley, "Contract Mania," China Bus. R., Sept-Oct. 1984 at 111.

65. See, e.g., Ta-Kuang Chang, Timothy A. Gelatt and, Corporate and Individual Taxation in the People's Republic of China (1985); Gelatt, "Legal and ExtraLegal Issues in Joint Venture Negotiations," J. Chin. L. 217 (1987).

66. In particular, the Practicing Law Institute has brought specialists together in a series of programs, see Legal Aspects of Doing Business With China, (Howard Holtzman ed. 1976); $A$ New Look at Legal Aspects of Doing Business With China: Developments a Year After Recognition (Howard Holtzman and Walter Surrey eds. 
These publications, however, have often been limited to commenting on new Chinese legislation relating to foreign trade, investment and taxation, and the scope for analysis is fundamentally confined by some characteristics of Chinese law reform itself. There is frequently less to analyze than foreign observers would like in new legislative developments in what the Chinese call "foreign economic law." In the typical pattern of Chinese law-making, a problem is first addressed by promulgation of a law that is at best general and often skeletal; this is eventually followed, sometimes years later, by relatively more detailed interpretive regulations. ${ }^{67}$ Foreign practitioners usually have little more to analyze than the bare texts of newly-promulgated laws and regulations, because they can necessarily only accumulate notions of practice that are impressionistic and scattered. Although application of laws across the country is decidedly not uniform and Chinese officials are likely to receive guidance on the interpretation and application of laws from internal bulletins and other material not available to foreigners, ${ }^{68}$ and only scattered interpretations of law and cases are published. Chinese sources such as ordinary newspapers or legal journals report only episodically and sketchily on practice and possible trends, and published discussions by Chinese legal scholars are usually exegetic.

In the absence of authoritative Chinese sources, an essential source of information on Chinese legal practice is China Law and Practice, a journal published in Hong Kong, as are the Asian Wall Street Journal and the Far Eastern Economic Review. Many articles published in the West about new developments are useful initially because they report on the texts of new laws but they may soon become outdated, often within months after their publication. Relatively few publications by China-practice specialists during the $1980 \mathrm{~s}$ went beyond chronicling recent developments to draw together characteristics of the system and features of Chinese practice as it

1979); Jerome Alan Cohen, Legal Aspects of Doing Business in China, (1983); Eugene A. Theroux, Legal Aspects of Doing Business With China 1986 (1986).

67. So, for example, the Law of the People's Republic of China on Joint Ventures Using Chinese and Foreign Investment, adopted in July 1,1979 , by the National People's Congress and promulgated on July 8, 1979 (1 China Lawos for Foreign Business para. 6-500 (1989)), was not supplemented by detailed regulations until promulgation of the Regulations for the Implementation of the Law of the People's Republic of China on Joint Ventures Using Chinese and Foreign Investment promulgated on September 20, 1983, by the State Council, Art. 100 Amended by the State Council January 15, 1986, 1 China Laws for Foreign Business para. 6-550 (1989).

68. See Lubman, "China Should Make More Laws Public," The Asian Wall Street Journal, Aug. 5-6, 1983; "Official Discusses Continued Use of Internal Regulations," Hong Kong AFP news release April 4, 1986; "Beijing to end secret directives on investors," South China Morning Post, January 13, 1987; "An End to Chinese Inscrutability," Time, Dec. 19, 1988, p. 65. 
affected foreign trade and investment. ${ }^{69}$

\section{Criminal, Civil and Economic Law; Dispute Settlement}

Scholarly articles on Chinese domestic legal institutions have multiplied rapidly as the institutions have grown, but most of them have been as exegetical as the literature on foreign trade and investment. An additional problem is created by the sociology of American legal scholarship. Unlike other academic professions in the United States, much legal scholarship is written and edited by students who have not completed their professional education. Most student authors of articles in the law reviews published by most American law schools ${ }^{70} \mathrm{know}$ little about China and less about Chinese practice; they often rely on articles by practitioners even though they rapidly become outdated, and on other law review articles! Most law review articles discuss little more than the texts of promulgated Chinese laws and regulations; although most of the student authors and editors have presumably been educated to question and analyze domestic U.S. statutes, they cannot handle Chinese statutes in a similar manner. The unfortunate consequence is that most American law review articles have given new Chinese legal institutions a greater appearance of solidity - sometimes downright unreal - than is warranted.

In addition, a separate trickle of articles on contemporary Chinese law offering little insight are written by practicing lawyers with no knowledge of China, who, having traveled to China are eager to share their impressions about it when they return. American lawyers and businessmen often write about China as if they are pioneering explorers, regardless of how many travelers preceded them. Assuming that their impressions are both novel and publishable, they are abetted by law review editors who help them add further to the masses of citations accumulated by non-specialists writing about Chinese law.

For the reasons discussed here, many U.S. law review articles and much of the writing on China by American lawyers has been of limited value. My impressionistic observations suggest that publications by European lawyers are no more nuanced. West European legal scholars, trained to emphasize promulgated codes as principal sources of law, have generally focused on the norms expressed in

69. See, e.g., Cohen and Valentine, supra n. 61; Lubman, "Equity Joint Ventures in China: New Legal Framework, Continuing Questions," supra n. 62; Gelatt, supra n. 65; Kolenda, "A Happy Ending: Buy-Out in Chinese-Foreign Joint Ventures," 24 Tex. Int $l$ L. J. 87 (1989). At the time this article was completed, Moser, supra n. 61 was the single most helpful volume available.

70. Approximately 200 student-edited law reviews are currently published in the United States. 
Chinese statutes and $\operatorname{codes}^{71}$ without referring to practice, and sometimes exaggerate the importance of these norms. In addition, the inadequacies of legal writing about China discussed here stem partly, I am sure, from the extent to which lawyers everywhere are concerned with the language of legal norms; unfortunately, gaps between written rules and actual practice yawn wider in China than in the West. Turning to scholarship by China specialists I note that several general surveys usefully summarize the extensive legislation of the $1980 \mathrm{~s},{ }^{72}$ and a few interpretive overviews have traced both genuine achievements and the continued tension between legality and politics. ${ }^{73}$ Among specialists, views have ranged from emphasizing the progress China made in promoting the rule of law since 1979,74 to arguing that the Chinese leadership has consistently used law to "legitimate the leadership's own power while erecting the edifice of technical guidelines" needed to facilitate economic reform and reassure foreign investors. ${ }^{75}$ Several have emphasized, as I have here, the potential that the legal reforms offered for promoting future legal development. ${ }^{76}$

In the areas of criminal law and procedure, despite codification and reinvigoration of the Procuracy and the courts, scholarship suggests little break with pre-reform practice. Western concepts such as

71. See, e.g., Dominique T. C. Wong, Les sources du droit de la Republique Populaire de Chine (1982).

72. See, e.g., the articles cited supra n. 33.

73. See, e.g., Dicks, supra n. 32; Cohen, "Tienanmen and the Rule of Law," in The Broken Mirror: China After Tiananmen 323 (George Hicks ed. 1990); Lubman, "Emerging Functions of Formal Legal Institutions in China's Modernization," 2 China L.R. 195 (1983).

74. See, e.g., Cohen, id. at 323 ("remarkable decade of progress toward creating a credible mule of law"); Chang, "The Making of the Chinese Bankruptcy Law: A Study in the Chinese Legislative Process," 28 Harv. Int 7 L. J. 333 at 371 (1987) (suggesting that the National People's Congress had the potential "to develop into a viable pluralistic force and form the basis for a nascent system of checks and balances.")

75. Alford, "'Seek Truth From Facts'-Especially When They Are Unpleasant: America's Understanding of China's Efforts at Law Reform," 8 Pac. Basin L. J. 177, 180 (1990).

76. See, e.g., Gelatt, "Law Reform in the PRC After June 4," $3 J$. Chin. L. 317, 318 (1989), acknowledging that "the PRC leadership has never indicated an intention to use law in a way that would alter China's political or ideological foundation or 'basis," " but arguing also that leadership reaction to the democracy movement of 1989 cannot be as extreme as the Anti-Rightist Campaign of 1957 or the Cultural Revolution, that legal reform has created both expectations among the Chinese people and an "interest group" among Chinese lawyers and academic specialists, and that the Democracy Movement symbolized concerns to establish a genuine rule of law. See also Cohen, supra n. 73 at 340: "Although legal institutions have been crippled, they continue to function and develop in non-political fields, and even today's truncated legal education and scholarship will keep alive legal ideas and goals despite the politicized environment." 
the presumption of innocence has been resisted, ${ }^{77}$ and the activity of the courts remained closely tied to the implementation of current policies. ${ }^{78}$

Civil and "economic" law, the most prominent areas of Chinese legal reform, have probably attracted the greatest scholarly interest. Extensive descriptive studies by Henry Zheng, a Chinese scholar writing in the United States, provide a useful introduction to the legislation, ${ }^{79}$ as do several thoughtful translations. ${ }^{80}$

Useful analytical work has also appeared. Howard Chao and the late Yang Xiaoping have demonstrated that a beginning has been made in using legal rules to change existing forms of ownership, stimulate the autonomy of state enterprises, experiment with securitization of state enterprises, and transform collectives into entrepreneurial enterprises. ${ }^{81}$ Chao and Yang also studied new laws on collective enterprises in the mid-1980s and concluded at the time that

"These new practices and laws make it possible for motivated associations of investors to more easily engage in cooperative economic activities and to manage them on an autonomous basis. These developments also have the potential of energizing the flow of domestic capital within China, by tapping the vast pools of Chinese individual and institutional savings." 82

The new private sector came under attack soon after their article was published, and Chao and Yang's conclusions would have to be modified if they were writing today. Still, their investigations into new areas of legal and economic activity will provide useful yardsticks with which to measure subsequent developments in the emergence - or suppression - of the private sector.

Scholars have begun to examine the influence of codification on the emergence of consciousness of legal rights. William Jones has examined the "General Principles of Civil Law," a partial codification, and concluded that it is too abstract to be useful in settling spe-

77. Gelatt, "The People's Republic of China and the Presumption of Innocence," 73 J. of Crim. L. \& Criminology 259 (1982).

78. See, e.g., Note, "Concepts of Law in the Chinese Anti-Crime Campaigns," 98 Harv. L. Rev. 1890 (1985).

79. Henry R. Zheng, China's Civil and Commencial Law (1988).

80. Grey and Zheng, translators, "General Principles of Civil Law of the People's Republic of China," $34 \mathrm{Am}$. J. Comp. L. 715 (1986); Basic Principles of Civil Law in China (William C. Jones ed. 1989).

81. Chao and Yang Xiaoping, "The Reform of the Chinese System of Enterprise Ownership," 22 Stan. J. Int l. L. 365 (1986).

82. Chao and Yang Xizoping, "Private Enterprise in China: The Developing Law of Collective Enterprises," 19 International Lawyer 1215 at 1237 (1985). 
cific disputes. ${ }^{83}$ By contrast, Pittman Potter has concluded of the Economic Contract Law, which applies to contracts between Chinese enterprises, that

“. . .the steps taken toward effective implementation of the law have contributed substantially to the acquisition of full abstract and practical legitimacy. These efforts and the legitimating consequences which they engender have provided an important foundation for the [Economic Contract Law's] capacity to stimulate the emergence of private economic rights in China." 84

Other research, based on a small number of cases in a Shandong county, suggests that "contracts and institutions for the formal resolution of disputes among more or less autonomous parties [have] become more much more important as an underpinning for off-plan economic transactions," 85 and that formal dispute resolution and lawyers are growing in importance.

The growth during the mid-1980s, both of unplanned economic transactions and of a private sector led to an increase in contract and property disputes, which in turn has stimulated interest in dispute resolution. Michael Palmer has suggested that extra-judicial mediation has become "more specialized, bureaucratic, vocational, and 'democratic' "86 by comparison with the 1950 s, and notes that in recent years mediation has been emphasized as supplementary and complementary to formal judicial action. Lawyers have begun to appear at mediation proceedings, and attempts have been made to raise the status of mediators. He states,

"there now seems to be less emphasis on using disputes to raise political consciousness and a greater concern to get to the basic facts of the case, to handle the disputes in an impartial manner, and to promote social stability and social morality."87

At the same time, the use of mediation to support current policies continues, frequently causing disputes to be politicized, although less

83. See, e.g., Jones, "Some Questions Regarding the Significance of the General Provisions of Civil Law of the People's Republic of China," 28 Harv. J. Int I. L. 309 (1987). See also Jones, "Civil Law in China," 18 China. L. \& Govt. 3 (1985-86).

84. Pittman Potter, Policy, Law and Private Economic Rights in China: The Doctrine and Practice of Law on Economic Contracts 609 (University of Washington: Ph.D. dissertation, 1985); See also MacNeil, "Contract in China: Law, Practice and Dispute Resolution," 38 Stan. L. Rev. 303 (1986).

85. Ross, "The Changing Profile of Dispute Resolution in Rural China: The Case of Zouping County, Shandong," 26 Stan. J. Int Z L. 15 at 61 (1990).

86. Palmer, "The Revival of Mediation in the People's Republic of China: (1) Extra-Judicial Mediation," in Yearbook on Socialist Legal Systems (William Butler ed. 1987), 219 at 226.

87. Id. at 261. 
insistently than during the $1950 \mathrm{~s}^{88}$ Palmer has noted also that although mediation in the courts has also been emphasized, some Chinese critics have argued that the scope of judicial mediation should be reduced. ${ }^{89}$ A striking fact, to which I return below, is that perhaps over seventy percent of all civil cases are settled through mediation after they reach the courts. ${ }^{90}$ Despite the rise of formal legal institutions, mediation continues to flourish as a basic form of Chinese dispute settlement.

In studying dispute settlement, the role of the emergent Chinese legal profession has aroused interest. Henry Pitney has concluded that "for the first time, China appears poised to provide legal services to large numbers of clients in rural and urban areas".91 At the same time, further development of the professionalism of Chinese lawyers is impeded by the low level of their training, the unwillingness of officials to provide information on bureaucratic practice, hostility directed by Chinese judges and police officials at energetic defense lawyers, and popular distrust of lawyers. ${ }^{92}$

\section{Cultural Influences}

Institution-building in recent years has further sharpened earlier interest in defining and assessing the influence of traditional institutions and values. The attractiveness of discovering neat continuities seems to persist. ${ }^{93}$ A more fundamental issue, however, may be the difficulty for Western students of transcending their own legal traditions when they try to understand China's.

For example, Roberto Unger has argued that China never developed a "legal order," the basic conditions for which he assumes to

88. See Palmer, id. at 262.

89. Palmer, id. at 167; Dicks, supra n. 32 at n. 111.

90. See Wang Jianping, "Judicial and Administrative Mediation in the People's Republic of China," unpublished paper, Harvard Law School, May 1984; Palmer, "The Revival of Mediation in the People's Republic of China: (2) Judicial Mediation," in Yearbook on Socialist Legal Systems 143 (1988). See also Chang, "Deciding Disputes: Factors That Guide Chinese Courts in the Adjudication of Rural Responsibility Contract Disputes," $52 \mathrm{~L}$. \& Contemp. Prob. 102, 113-14 (1989) (resolution of disputes "through the offices of a court" exceptional, and even if suit is brought, the courts prefer to turn cases over to local government agencies for resolution, usually mediation).

91. Pitney, "The Role of Legal Practitioners in the People's Republic of China," 24 Stan. J. Int' L L. 323 at 387 (1987).

92. Id. at $326,347$.

93. For recent assertion of links between contemporary practice and traditional philosophy see, e.g., Leng and Chiu, supra n. 2 at 170; Townsend, "The Concept of Law in Post-Mao China: A Case Study of Economic Crime," 24 Stan. J. Int Z. L. 227 (1987). I do not reject the influence of traditional philosophical ideas on contemporary institutions, but share the insistence that "What is important is not identities but the possibility of meaningful comparisons." Benjamin I. Schwartz, The World of Thought in Ancient China 3 (1985). 
be pluralism and belief in divine law.94 Adapting Max Weber's analysis of Western legal development, Unger emphasize China's failure to differentiate adiministrative commands from rules of law, to develop a legal profession, and to distinguish legal discourse from moral or political discourse. William Alford has criticized Unger's speculation for being based on the ethnocentric assumption that because a system did not develop Western conceptions of rights, it is therefore not classifiable as law. ${ }^{95}$ Alford also argues that Unger's treatment of the Chinese legal tradition is superficial and incomplete. ${ }^{96}$ Alford's argument of ethnocentrism seems apt, considering that Unger clearly relies very heavily on characteristics he has abstracted from Western European history and that Unger takes "the legal order" to be illustrated by "the distinctive legal systems established in Europe."97

In a study of the criminal process under the Qing dynasty, Alford underscores the need to be self-conscious about using concepts and standards derived from the Western legal tradition to evaluate the legal institutions of a society "removed from our own both culturally and temporally." $98 \mathrm{He}$ urges that we deepen our analysis of the cultural context in which the traditional criminal justice process operated, and weigh "with greater seriousness than is now the case the rhetoric and consciousness of those abroad we would study".99 In studying the "intended function and actual operation"100 of traditional law, we may discover that values and institutions in Chinese society may have served functions analogous to those of law in Western society. ${ }^{101}$

Alford uses Unger as an example of excessive readiness of American legal scholars to apply Western notions such as the separation of powers to buttress conclusions that the Chinese bureaucracy in the Qing dynasty was more concerned with strengthening control over the populace than with reaching just results in specific cases. His own attempt to suggest the concerns of the Qing criminal process with justice is based on only a single case and therefore seems unconvincing, ${ }^{102}$ but he persuasively argues a broader theme

94. Roberto M. Unger, Law in Modern Society 66-110 (1976).

95. Alford, "The Inscrutable Occidental: Implications of Roberto Unger's Use and Abuse of the Chinese Past," 64 Tex. L. Rev. 915 (1986).

96. Id. at 923-52.

97. Unger, supra n. 94 at 101.

98. Alford, "Of Arsenic and Old Laws: Looking Anew at Criminal Justice in Late Imperial China," 72 Calif. L. Rev. 1180, 1248 (1984).

99. Alford, "On the Limits of 'Grand Theory' in Comparative Law," 61 Wash. $U$. L. Rev. 945, 947 (1986).

100. Alford at 1245.

101. Alford, id.

102. I doubt that even extensive research is likely to disturb the established scholarly views of the traditional Chinese criminal process as harsh. Alford argues 
that is relevant here, the need to avoid using purely Western perspectives and to continue to reexamine traditional Chinese institutions in order to be alert to cultural influences on contemporary law-related behavior. ${ }^{103}$

Further research may illuminate, for example, Chinese conceptions of private rights. In imperial China the apparatus of informal rule formed by family, clan, guild, and other organizations augmented the slender resources available to imperial institutions to keep order and settle disputes. ${ }^{104}$ Research on 19th-century Taiwan suggests that although civil litigation was as infrequent and shunned there as it was on the Mainland, customary practice in contractual matters was so widely-recognized that it supported enforcement of claims arising out of commercial contracts which would be characterized in Western jurisprudence as creating rights. ${ }^{105}$ Further research into traditional custom and practice should yield additional evidence that these informal institutions protected many private claims. In China today, where informal dispute settlement is still favored, cultural values that long antedate Chinese Communism and

that we may find in the Chinese tradition beliefs and practices that supported values analogous to some associated with law in the West. He notes that integrity, competence and virtue in the officials who administered the system were highly prized. They were subject to strict rules governing the use of their discretion and the conduct of their offices, and they could be punished for errors committed in carrying out their professional duties.

To illustrate that the system while doing justice in its own terms could also do justice in ours, Alford relies on one notable case in which an unjust verdict was overturned by the emperor in Beijing, who also ordered the punishment of officials who had reached the incorrect decision. The case, however, may be an exception that proves the rule: justice was done only after many of the major defects for which conventional Western scholarship has criticized the Qing criminal process had appeared in every major stage of the case.

Recent expression of a view more consistent with Alford's is Ocko, "I'll Take It All The Way to Beijing: Capital Appeal in the Qing," 47 J. Asian Studies 291 (1988); see also Brian E. McKnight, The Quality of Mercy: Amnesties and Traditional Chinese Justice (1981).

103. Further study of traditional criminal law will no doubt add further important nuances to a legal system which, because of its temporal and cultural distance, is often treated in a highly abstract manner. See, e.g., a reexamination of the common Western view that punishment for crimes was believed to be required in order to restore "cosmic harmony," MacCormack, "Natural Law and Cosmic Harmony in Traditional Chinese Thought," 2 Ratio Juris 254 (Dec. 1989). Analyzing a portion of the Qing criminal code in search of underlying unifying concepts is Jones, "Theft in the Qing Code," 30 Am. J. Comp. L. 499 (1982).

104. See, e.g., Sybille Van der Sprenkel, Legal Institutions in Manchu China (1962):

105. Brockman "Commercial Contract Law in Late Nineteenth-Century Taiwan," in Essays on China's Legal Tradition, supra n. 17 at 76. In an earlier time, state officials may have been more involved; see Scogin, "Between Heaven and Man: Contract and the State in Han Dynasty China," 63 S. Calif. L. Rev. 1325, 1402 (1990): "As the first long-lasting unified Chinese Empire [the Han] extended the principle of state responsibility for the adjudication of disputes." 
patterns of organization will undoubtedly affect customary contractual practice and dispute settlement.

\section{Devising a Research Strategy}

\section{A. Chinese Limits}

Even the brief summary of research set forth above should indicate that the depth and scope of foreign studies of Chinese law are necessarily limited. Chinese legal institutions are novel, fragile and incomplete; opportunities to study them in action do not yet exist; most of their practice cannot be ascertained. Other limits, however, are placed by foreign students on their own inquiry. This section first discusses the limits set by Chinese institutions themselves, and then speculates on others of a very different kind that are embedded in Western scholarly perspectives.

1. The Lack of an Integrated Legal System: The Primacy of Policy; Law as an Instrument of Administration

Limits on study flow from the limits of legal reform itself. China does not yet have a legal system. Formal legal institutions are neither functionally well-differentiated from other institutions wielding state power nor permitted to operate with a high degree of regularity. Law and policy remain linked, and legality is necessarily weak. China does have a growing body of formal legal institutions - promulgated norms and agencies of the state that have begun to interpret and apply these norms with some regularity.

Much power, however, continued to be denied to these institutions. The separation of Party and government, although discussed during the $1980 \mathrm{~s}$, was not seriously undertaken. In criminal cases the CCP still dominates the work of the courts, police and procuracy, ${ }^{106}$ and the same seems true in civil cases. ${ }^{107}$ In the economy, although legal rules intended to guide the conduct of enterprise managers and officials have multiplied, the members of neither group are accustomed to guiding their conduct according to preestablished legal standards. The flux and uncertainty that have marked Chinese economic policies, the erratic pace of economic reform and popular doubts about the durability of policy changes further impede the regularized application of legal rules.

106. See, e.g., Note, supra n. 78; Lubman, "Emerging Functions of Formal Legal Institutions in China's Modernization," 2 China L. Rep. 195 at 245-49 (1983); Koguchi, "Some Observations About 'Judicial Independence' in Post-Mao China," 7 Bost. Coll Third World L.J. 195 (1987).

107. See, e.g., Chang, supra n. 90; Zweig, Hartford, Feinerman, and Deng, "Law, Contracts, and Economic Modernization: Lessons from the Recent Chinese Rural Reforms," 23 Stan. J. Int l L. 319 (1987), discussed below at text beginning at $n .188$. 
Chinese legal institutions could acquire substance and vitality only through great efforts over a long period of time. Nothing less is needed than changing the habits of thought of Chinese officials and the Chinese populace about the function and purpose of legal institutions; sustained and vigorous support by the Chinese leadership of such changes is essential to stimulate such changes. ${ }^{108}$ To overcome the combined inhospitability of Chinese traditions and the Chinese revolution to law and legality, policy would have to become and remain unequivocal about the basic direction of legal reform and about the values it is intended to promote.

Yet even before June 1989 the Chinese leadership itself had been unable to agree on a shared vision of the Chinese society and economy of the future or, consequently, of the goal of legal reform. ${ }^{109}$ Even incremental reform is impeded by ideology. In China today, institutional innovations must supposedly be consistent with a Marxist-Leninist-Maoist ideology that still cannot be directly challenged or repudiated, as similar ideologies have been in Eastern Europe and the Soviet Union. The nature of the obstacle presented by ideology is illustrated by the issue of redefining property interests. The first decade of economic reform heard much debate on competing conceptions of property. Piecemeal legislation was enacted after much debate about such innovations as expanding peasants' right to lease land, enlarging the autonomy of enterprise managers, and introducing share ownership in enterprises. Some scholars have urged abandoning state ownership altogether, ${ }^{110}$ while others have argued for the need to redefine the simplistic concept of "ownership of the whole people," a term that presently encompasses both land and state-owned enterprises. Some progress can be envisaged through piecemeal legislation behind a superficially intact facade of political cliches, ${ }^{111}$ or even in practice through usage by peasants uncon-

108. Although there are limits, of course, on the extent to which law reform directed by orders from Beijing can be effective. As one observer has commented, " 'law from above' is unlikely to provide a foundation for social consensus." Barrett L. McCormick, Political Reform in Post-Mao China: Democracy and Bureaucracy in a Leninist State 127 (1990).

109. Among the issues on which different views have been expressed, for example, is the relationship between law and policies such as those which aim at economic reforms. Should law follow policy, by translating into legislated rules policies that have been the subject of experimentation, as Peng Zhen, for one, has suggested? See, e.g., "Peng Zhen Views Political, Judicial Work," Hongqi [Red Flag] May 1, 1987, FBIS, Daily Report: China, 13 May 1987, 163. Or should law sometimes lead policy, as some legal scholars have suggested? See, e.g., Sun Guohua, "On Bringing Reform Into the Orbit of the Rule of Law," FBIS, Daily Report: China, 16 February $1989,19$.

110. See, e.g., "Property to the People," Far E. Econ. R., 22 December 1989, 12-13; "Article Urges Property Rights Revolution," FBIS, Daily Report: China, 16 November 1988,38 .

111. See, e.g., Tang Yungbin, "Urban Land Use in China," 53 Land Use Policy at 
cerned about ideology. ${ }^{112}$ Continued open reform would challenge concepts that have been frozen since the 1950s into crude categories derived from Marxist theory, and would sharpen tensions between actual practice and the legal concepts supposedly applicable to it.

Although the sophistication of Chinese leaders undoubtedly varies, probably the most common thread in Chinese leadership policy toward law has been treatment of it as "a tool of state administration." 113 No greater autonomy is likely to be granted to law without extensive political reform, ${ }^{114}$ and the events of June 1989 are only the most dramatic and tragic demonstration of the hostility of China's leaders to such reform. In the absence of fundamental political reform that would validate abandonment of the reigning ideology, Chinese law is likely to retain the tentative quality it acquired during the 1980s. If so, it will remain an assortment of disparate institutions lacking some of the elements that Western ideals take as essential in a meaningful formal legal system such as a hierarchy of sources of law, differentiation from other organs of state power, procedural regularity and control of discretion in decision-making, and adherence to professional values among the officials in the system.

\section{Novelty and Formalism in Chinese Legal Institutions}

Most of China's currently effective statutes and regulations first appeared only during the 1980s. Efforts to create or revive institutions such as the courts, the bar, notarial offices, arbitration of contract disputes, and judicial review of administrative acts are also relatively recent and incompletely implemented. The very novelty of these institutions limits the development of their regularized operation.

The new institutions are often treated formalistically. Chinese law has been imposed on Chinese society from the top down, and it is too early to assume that it has become rooted in Chinese society.

57-58 (January 1989) suggesting verbal formulas for attributing value to land while maintaining formal consistency with Marx's idea that land lacked value.

112. See, e.g, Sulamith H. Potter and Jack M. Potter, China's Peasants: The Anthropology of a Revolution 334 (1990): "The conditions of land tenure under present policy represent a return to pre-Liberation conceptions of property right. . production responsibility land is being assimilated into institutional patterns of land tenure and inheritance which once defined the use of private property. It is increasingly a formality to claim that the land is collective property and will remain so, or that such collective ownership will serve as an effective basis for sustaining socialism in the Chinese countryside."

113. Alford, supra n. 75 at 182.

114. Accord, Tao Dehai, "China Democracy Movement and Legal Crises," 8 Pac. Basin L. J. 390, 407 (1990): ". . unless the Chinese government decides to make the difficult but courageous choice of democratizing their political structure, as most of the East European communist parties have now done, legal crises will never be solved by legal means and justice will never be achieved in China." 
Chinese leaders and officials frequently refer to the current "lack of perfection" of the legal system, but their invocation of "perfection" reflects a narrow emphasis on the quantity and the texts of rules rather than on their application. Promulgation of a law is often treated as having created obedience to it, ${ }^{115}$ all the more paradoxical because the primacy of such norms as the basic rules for the operation of Chinese courts and other government agencies has not yet even been established in practice, and many laws and regulations that are applied by Chinese agencies are secret and unpromulgated!

Chinese legal formalism is buttressed by positivism to emphasize the legislature as the sole source of law and to limit the role of courts. Although progress has been made in publishing collections of laws, ${ }^{116}$ relatively little can be learned about their application and interpretation in practice. Theory denies binding and precedental force to judicial interpretations of laws. ${ }^{117}$ Although the Supreme People's Court publishes in its Gazette opinions on typical cases selected for "guidance" of lower courts and general prospective interpretations of laws, 118 it contains only a fraction of rulings and interpretations on national legislation. ${ }^{119}$

Chinese legal theory also seems to lead to the conclusion that if

115. Compare, e.g., Chen Shouyi, "A Review of Thirty Years of Legal Studies in New China," 2 J. Chin. L. 180, 196 (1988) ("Following the Third Plenum [of the Eleventh Party Congress of the CCP] the Central Committee abolished the practice of having the Party committee at the level of the deciding court approve cases,and directed that all practices that did not accord with legal regulations must be eliminated so as to ensure that judicial organs exercise their authority independently") with Koguchi, supra n. 106 at 202, citing ample evidence on which to base his conclusion that "There is no doubt that the Party and not the court was, and is, the real decision-maker in P.R.C. adjudication. The Party is clearly the center of judicial power." For another example of formalism see also "Citizens Can Sue Officials Under New Law," China Daily, Jan. 10, 1990: “The Ministry of Public Security will conduct a thorough check of police performance in the coming months to correct illegal actions before the Administrative Procedure Law becomes effective in October."

116. In addition to yearly compilation of laws and regulations enacted by the $\mathrm{Na}-$ tional People's Congress and its Standing Committee, the Collection of Laws and Regulations of the People's Republic of China [Zhonghua renmin gongheguo fagui huibian], laws and regulations have been collected in special compendia such as the Institute of Law of the Chinese Academy of Social Sciences, Collection of Laws, Regulations and Documents on China's Economic Management [Zhongguo jingöi guanli fagui wenjian huibian] (1985).

117. See, e.g., Tao-tai Hsia and Constance A. Johnson, Law Making in the People's Republic of China: Terms, Procedures, Hierarchy, and Interpretation 20 (1986). Arguing for giving greater weight to cases is Cao, "Borrowing the Case Law Method to Promote the Construction of the Legal System in Reform," Renmin ribao (People's Daily) Mar. 3, 1987.

118. Liu, "'Judicial Review' in China: A Comparative Perspective," $14 R$ Soc. $L$ 241 at $246-50$ (1988).

119. Consistency within the judicial system could theoretically be promoted by publications for internal use only. Accord, Chang, supra n. 90 at 117, n. 52. Although informative collections of cases have in fact been published in recent years, they are unofficial. Sidel, supra n. 33 at 258-61. 
the courts do not create law, then there is little need to publish judicial decisions to illustrate practice. As a result, systematically assembled collections of cases and administrative interpretations of existing normative rules generally remain unpublished. Moreover, Chinese judicial decisions are terse summaries with little analysis of the reasoning that underlies the result, so their value for observers, foreign or otherwise, is necessarily limited. One student has concluded,

"the researcher is forced to rely on secondary sources - articles in legal journals, newspaper reports, and published collections of cases - which are usually simplified accounts that provide only a glimpse into the judicial process."120

Most Chinese discussions of law do not reflect the recognition in Western legal systems that law is dynamic and that courts and administrative agencies make law when they interpret it. The positivist views of law that currently seem to mark Chinese legal theory resemble those which dominated both Continental and Anglo-American law in the late nineteenth and early twentieth centuries, before the notion that law could be "complete" was shattered in the United States and Europe alike.

Formalism is evident also in treatment of American and other foreign legal systems. For what purposes and where should Chinese study foreign law? Study and research abroad by Chinese law professors, judges, lawyers and students should help them gain insight into the legal institutions and legal cultures of the countries in which they study. Sometimes, though, Chinese interest is expressed in a desire to "borrow" foreign legal institutions. An extreme example is the notion that many of Hong Kong's laws could be transplanted en bloc to special investment areas in China. ${ }^{121}$. Such Chinese hopes show surprisingly little understanding about the difficulties inherent in transplanting foreign legal institutions to China, or to any country with a vastly different history and culture.122

Underlying Chinese formalism are more fundamental problems. The framework of rules that took shape in the 1980s constitutes only the outline of a legal system. The content, meaningfulness and impact of these rules are still unclear and are likely to remain so for a long time. Perhaps application in practice by administrative agencies and courts could widen them into a net of substantive rules that

120. Chang, supra n. 90 at 117.

121. See, e.g., "Commentary on Applying Hong Kong, Foreign Laws," Beijing, Xinhua News Agency, 22 December 1988.

122. Cao, "Borrowing the Case Law System to Promote the Construction of Legal System in the Reform," Renmin Ribao (People's Daily), 13 March 1987, and see also Renmin Ribao (People's Daily)(Overseas Edition) 25 March 1989, quoting Cai Zheng, Minister of Justice, on Chinese interest in England's "precedent system" (pan-li). 
would significantly influence the behavior of economic actors and government officials. Perhaps repetition, habit, and greater stability of expectations could thereby be promoted. These have been the hopes of some of the architects of the Chinese legal system and of some Chinese legal scholars. ${ }^{123}$

But even under the best of circumstances considerable time would be required to permit evolution of a substantial and coherent body of legislatively-promulgated rules, administrative and judicial interpretations and scholarly doctrine. In the meantime, foreign and Chinese scholars alike engaged in research on Chinese law have much less to work with, whether using conventional or. unconventional sources, than if they were focussing their attention on a legal system with a longer and more continuous history.

\section{Studying Chinese Law in the PRC}

Students of Chinese law in the United States and abroad have been hard put to keep abreast of the flood of Chinese legislation and publications on legal developments. Moreover China itself, now somewhat more accessible to scholars, presents the challenge of deepening foreign studies of Chinese law in ways not even conceived of when some of the scholars active in the field today began their training. China's accessibility, however, is often illusory.

For American students of Chinese law, China only seems to have become more approachable. The Chinese policy of "opening" Chinese society has fostered legal educational exchanges which have largely been one-way in bringing Chinese legal scholars to study at American law schools. Although American lawyers and law professors have traveled to the PRC to lecture and teach on American law and, sometimes, to discuss proposed Chinese legislation, foreign scholars of Chinese law have encountered great difficulties in their attempts to study law in China.

The continued overt links between law and politics make legal research particularly sensitive and potentially controversial. Americans have attended courses at Chinese law schools but their access to libraries has been obstructed, partly because many legal books and journals are "neibu", for internal use only. Reflecting general Chinese reluctance to permit field research by foreign scholars, ${ }^{124}$

123. See, e.g., "China Daily Commentator on Need for Rule of Law," China Daily, 17 July 1986; "Feudal Concepts of Law Still Exist in China," Zhongguo Fazhi Bao, (China Legal Daily) 23 Oct. 1986; Qi Haibin, "Roundup of the 1988 National Symposium on Legal Theory," FBIS, Daily Report: China, 13 Sept. 1988, 41.

124. See, e.g., David M. Lampton, with Joyce A. Madancy and Kristen M. Williams, A Relationship Restored: Trends in U.S.-China Educational Exchanges, 1978 $1984139-40$ (1986) on the difficulties encountered by American sociologists and anthropologists who have sought to do field work in China, and concluding (at 165) 
research outside universities, such as at law courts or law offices, was almost impossible to arrange before. June, 1989 and meaningful opportunities to study legal institutions at work remain practically nonexistent. ${ }^{125}$

After June, 1989 the prospects for expanded research opportunities for Americans interested in Chinese law grew dimmer than before, although legal exchanges continued in somewhat truncated form. If American law schools and organizations that sponsor legal studies by Chinese in the United States insisted more energetically on greater reciprocity than presently exists, they might eventually expand research opportunities. The continuing difficulty of conducting research in depth on Chinese law is all the more reason for paying close attention to foreign perspectives on studying it.

\section{B. Limits Imposed by Foreign Concepts}

\section{General}

The incompleteness and novelty of Chinese legal institutions also challenge foreign students to attempt to understand processes that are at work before our eyes. Exegesis whether in the West or China, exaggerates the importance of written law, but what alternative approach might offer a means of going beyond the letter of the law to gain insight into the operation of legal institutions in Chinese society? The balance of this article speculates on an appropriate research strategy.

Students of foreign law are always "in danger of uncritically transferring to [the foreign law] the assumptions which we make about the underlying foundations of our own law."126 When careful comparatists study specific problems or institutions in legal systems with similar levels of development, their own rigor in defining the subject of study and its social context leads to insightful study. ${ }^{127}$ The literature of what is conventionally called "comparative law", however, offers no methodology to help the foreign observer avoid uncritical assumptions or otherwise aid him to comprehend foreign legal institutions in their social context. ${ }^{128}$

that "social and natural scientists have been hampered by restrictions on field research in China, and these restrictions have substantially reduced the benefits of exchanges from the American perspective."

125. See, e.g., Chang, supra n. 90 at 121, who conducted research in China in 198586 on judicial decision-making in rural contract disputes: "Access to primary judicial materials and judicial personnel is extremely limited. The Chinese judicial system remains essentially a closed institution, largely impenetrable not only to foreigners but also to most Chinese."

126. Berman, "Soviet Perspectives on Chinese Law," in Cohen supra n. 3 at 313.

127. See, e.g., John P. Dawson, A History of Lay Judges (1962).

128. Compare Alan Watson, Legal Transplants: An Approach to Comparative Law 11 (1974): ". . . Comparative Law can hardly be systematic. . .; any study of Com- 
Difficulties increasse, of course, as the cultural distance between the observer and the system under study widens. Sometimes it may be necessary to conclude that comparison "between particular parts of [the Chinese and other legal] systems. . . seems hardly appropriate,"129 but even if not, as I have noted elsewhere, "of all the disciplines that can be used in the West to study China, law seems the most difficult to use meaningfully because it is so rooted in Western values."130 An important example, because of its centrality in our understanding of Chinese society, is the difficulty of studying Chinese concepts of rights.

\section{The Problem Illustrated: Analyzing Chinese Conceptions of Rights}

For Chinese legal development to be meaningful, individual citizens, groups, enterprises and organizations must be enabled by rules enforced by the power of the Chinese state to protect themselves against official arbitrariness and to enhance the stability of expectations arising out of their economic transactions. This is not merely the conclusion of a foreign observer, but the distillation of recent discussions and statements about law that have appeared in Chinese legal publications and the general press. ${ }^{131}$ In a Western legal system we would talk about "rights". But in China what content would such rights or their analogues possess, especially those which the individual could assert against the state? By what standards, using what categories of inquiry, are they to be understood? Foreign scholars are tempted to rely on intellectual categories supplied by their own legal system, shaped by traditions and history that are difficult to transcend.

Some American scholars of Chinese law have not hesitated to project Anglo-American concepts of due process onto Chinese law. ${ }^{132}$ Others, reluctant to accept intellectual categories that seem culture-bound, have argued that because China is a poor and developing country, "economic and social rights may be much more important than political and civil rights,"133 and that Chinese

parative Law will be subjective, and no objective test will demonstrate that the aspects considered were the most appropriate and the only ones appropriate."

129. Dicks, supra n. 32 at 542 .

130. Lubman in Cohen supra $n .3$ at 260.

131. See, e.g., the articles cited supra n. 123, and Wang Jiafu, Liu Hainian and $\mathrm{Li}$ Buyun, "A Discussion of Legal System Reform," Faxue Yanjiu [Jurisprudential Research], 2 (1989), 1.

132. See, e.g., Cohen, "Due Process?," in The China Diffenence 237 (Ross Terrill ed. 1979); Edwards, "Civil and Social Rights: Theory and Practice in Chinese Law Today," in Human Rights in. Contemporary China 42 (R. Randle Edwards, Louis Henkin, and Andrew J. Nathan eds. 1986).

133. Li, "Human Rights in a Chinese Context," in Terrill, id. at 221. 
underemphasis on individual rights is understandable in light of the importance in Chinese tradition on the behavior of the individual in a group. In this view, the assumption that a legal system should protect human rights may be irrelevant to understanding Chinese law and Chinese society. In a similar view, analysis derived from AngloAmerican concepts of legal procedure overlooks a historical Chinese lack of concern for "procedural justice," even though "substantive justice" may have been important. ${ }^{134}$

The foreign student cannot ignore the roots of Chinese conceptions of rights in traditions very different from their Western analogues. Some of the differences are illustrated in documents of a constitutional nature proposed or adopted in China since the beginning of the twentieth century, all of which, it has been observed, have consistently treated rights as contingent. Common to all of them are the ideas that

-rights are granted by the state and can be changed by the state;

-rights are goals to be reached rather than prerogatives of personhood; and

-government can limit rights by legislation, and is not itself restrained by law. ${ }^{135}$

Yet even if many Chinese officials and much of the Chinese

134. ". . . if undertaken honestly' and with intellectual rigor, a broader definition of human rights need not fall victim to the myopia of cultural relativism," Potter, "Human Rights in China: The Interplay Between Political and Socioeconomic Rights," Amer. Bar Found. Res. J. 617 at 619 (1987).

135. The analysis is of such fundamental relevance to research on Chinese law that it merits quotation at length here: "The [Chinese] tradition was shaped by a theory of the unlimited scope of state power that interpreted foreign theories of law in the light of ideas from the Chinese tradition. Second, rights were interpreted in terms of long-standing Chinese views on the relation between individual and collective interests, on political obligation and moral heroism, that interacted with Western individualistic and Marxian currents of thought. Third, the Chinese understanding of political democracy integrated Western theories with traditional schools of thought on the relations between people and state. Finally, the Chinese discussion of political rights drew in the modern idea of social utility, understood in the light of China's condition of backwardness." Andrew J. Nathan, Chinese Democracy 113 (1985). He further notes that the

"philosophy of law as the state's will and rights as the state's creation ... helps explain several of the characteristics of the Chinese constitutional tradition. First, if rights are created by the state, it is reasonable for rights provisions to be programmatic ... Second, it is reasonable for the state to grant rights only to those who are friendly or loyal to it or who are its 'members,' and to deprive of rights those who are hostile to its purposes ... Third, since the state creates rights it is reasonable that it have full powers to restrict them, so long as it does so in the same way that it grants them - by legislative enactment . . . Fourth, since the state acts legitimately when it restricts rights by law, no law can be held invalid because it restricts rights, and no procedure is needed to determine whether particular laws do violate rights." Id. at 116.

Consistent with this view, a common thread of authoritarianism can be perceived in political reforms advocated by Chinese leaders as diverse as the Empress 
populace alike share these authoritarian values, concern for due process values has increasingly been voiced in China, by Chinese, in recent years. Chinese leaders have been consistently concerned about the need to curb official arbitrariness. Some Chinese legal scholars, officials and intellectuals have called for a legal system that embodies standards of procedural fairness. Since 1978, published discussions of political and legal reform, as well as demonstrations by Chinese students in the name of democracy, have increasingly called for the rule of law. ${ }^{136}$ These are indigenous Chinese sentiments, not the creations of Western scholars, and they signify that the rule of law is becoming a Chinese problem. Such developments suggest, as Jerome Cohen urged as early as 1977, that the argument that "such due process values, as we call them, are irrelevant to China ... is [an argument] of extreme cultural and political relativism."137

The preferred alternative to such relativism, however, is not necessarily the use of Anglo-American concepts of due process as analytical categories. These and broader human rights standards easily become standards for judgment, especially since the suppression of the democracy movement in 1989. The human rights movement has broad appeal, and not only in the West. A distinguished scholar has argued that the concepts articulated in the Universal Declaration of Human Rights are not rooted in any particular philosophy, ideology or social system, ${ }^{138}$ and that "the world has placed its faith in them and called on states to respect and ensure them."139 But if "active human rights policy is always the expression of the element of idealism in foreign policy,"140 the application of due pro-

Dowager, Chiang Kai-shek and Deng Xiaoping. Cohen, "The Post-Mao Reforms in Historical Perspective," 47 J. Asian Studies 519 (1988).

136. The most scholarly account of the democracy movement in China before 1989 is Nathan, id. at 3-30, 193-232; on the events of Spring, 1989, see, e.g., Andrew J. Nathan, China's Crisis 171-92 (1990). Nathan's books contain the most thoughtful writing on a highly controversial and emotion-charged subject. Among the torrent of books and articles that appeared after June, 1989, see also Han Minzhu, Cries for Democracy: Writings \& Speeches from the 1989 Chinese Democracy Movement (1990); Andrew Walder, "The Political Sociology of the Beijing Upheaval of 1989," 38 Problems of Communism (Sept.-Oct. 1989) 30. Among Chinese articles relating law to democracy see, e.g., Chen Yusheng, "Politics Without Law is Dangerous Politics," Faxue [Jurisprudence] 1 at 2-3 (1987) an outspoken call for the rule of law by a scholar at the Institute of Law of the Chinese Academy of Social Sciences. See also "Article on Building Parliamentary Democracy," FBIS, Daily Report: China, 15 December 1988, 15, translating an article by Cao Siyuan in the Shanghai World Economic Herald proposing amendments to the Chinese Constitution which include adoption of the presumption of innocence in criminal cases.

137. Cohen, supra n. 132 at 239.

138. Henkin, "The Human Rights Idea in Contemporary China: A Comparative Perspective," in Human Rights in Contemporary China supra n. 132 at 7-13.

139. Id. at 19.

140. Pflueger, "Human Rights Unbound: Carter's Human Rights Policy Reassessed," XIX Pres. Stud. Quart. 705, 714 (No. 4, 1989). 
cess and human rights standards to China necessarily also imports idealism into scholarship. Caution seems necessary in order to avoid transforming scholarship into a rush to judgment.

Human rights may express widely-shared ideals, but they are necessarily refracted through the political ideology of the individuals who believe in them, including scholars. The foreign student of another society must be wary of the capacity of his ideology to shape his scholarship even if, as is the case here, the ideology seems both benign and widely supported. As obvious as this has been in the past, ${ }^{141}$ the caution is still appropriate. Both before and since the Chinese government's brutality in Beijing in 1989, censorious judgments have been pronounced on China by some Americans, including members of Congress who would punish the Chinese leadership for meeting American ideals. ${ }^{142}$

Especially in the wake of the Tiananmen events, apposite here is what one American China scholar, writing about swings in American perceptions of China during the 1970s, has called the "persistent tendency to make sweeping moral judgments about China" and the apparent conviction "that the only way to remedy misunderstanding is to turn it on its head."143 Even when analyzing the Chinese leadership's repressive policies and its cynical use of the law, scholars must resist the temptation to give "familiar language about rights and procedural safeguards ... the connotations that such language carries in our own legal culture."144

Chinese conceptions of legal rights - tentative, incomplete, and fragile - obviously will be shaped by values derived from Chinese tradition, and which are themselves in the course of change. Analytical categories other than familiar Western concepts will be difficult to construct, but foreign observers must attempt to imagine them anyway in order to be sensitive to possible differences between Chinese and Western conceptions. China's very differentness is helpful, because it should prompt the Western student to abandon some common assumptions about legal institutions and their growth anywhere that might otherwise impede study. For example, to take some ideas that have been much questioned in recent American

141. See, e.g., Pfeffer, supra n. 12 at 276, warning against comparisons of the Chinese criminal process "with. . idealized and misleading images of the American process."

142. See, e.g. Roberta Cohen, People's Republic of China: The Human Rights Exception (1986); Human Rights in the People's Republic of China (Wu, et al., eds. 1988); Bernstein, "Break Up the Chinese Gulag," New York Times, Feb. 17, 1991, p. E13; Pelosi, "Attach Strings to Favorable Status," San Francisco Examiner, May 17, 1991.

143. Harding, "From China with Disdain: New Trends in the Study of China," XXII Asian Survey 934, at 952 (1982).

144. Alford, supra n. 99 at 954 . 
scholarship, serious students of Chinese law are not likely to entertain notions about the centrality of law in Chinese society; ${ }^{145}$ they are not likely to assume that law and society have clear boundaries and ignore their interpenetration; ${ }^{146}$ and they are not likely to assume that legal institutions develop along a predictable evolutionary path. ${ }^{147}$

\section{Possibilities: Emphasizing Function and Cultural Context}

The perils of cultural relativism and ethnocentricity are easy enough to condemn, but devising a research strategy that will avoid them is much harder. In discussion below I have suggested an approach which, while not purporting to be precise, seems at least nonetheless to embody an appropriate manner of responding to some of the intellectual challenges presented by the study of contemporary Chinese law. I have urged that acting tentatively and self-consciously while resisting the appeals of high levels of abstraction, we should improvise a sociology of Chinese law even before Chinese law has itself become coherent. In addition to examining legal rules and doctrine, policies, and patterns of behavior by legal and economic actors, we must try to understand the social functions of institutions and the values and expectations related to law that are held both by officials and members of the populace.

\section{Searching for Function}

I begin with an inquiry that is conventional enough, into formal legal rules, at least to determine the intentions of the legislative draftsmen and the policy-makers they serve. ${ }^{148}$ For example, analysis of Chinese legal materials such as widely-used textbooks suggests the extent to which civil law is meant to give legal expression to progress toward establishing a market economy in China. ${ }^{149}$ In a re-

145. See, e.g., Schwartz, "Law and Normative Order," in Law and the Social Sciences 63 (Leon Lipson and Stanton Wheeler eds. 1984). 61.

146. See, e.g., Gordon, "Critical Legal Histories," Stan. L. Rev. 36 (1984), 57 at 60-

147. See, e.g., Gordon, id.

148. Sometimes, even the promulgation of a statute or other legal rule may contrast with previous use in the PRC of formal legal norms merely to "summarize" policies that had already been implemented. Indeed, to the extent that the new laws are promulgated to implement new policies before such policies are considered to have been tested in practice, their use is novel. See, Sun Guohua, "On Bringing Reform Into the Orbit of the Rule of Law," Guangming Ribao, 7 Feb. 1989, translated as "Article Views Reform, Rule of Law," FBIS, Daily Report: China, 16 Feb. 1989, 19 , suggesting that laws can be "effective weapons pointing the direction of reform."

149. Discussing the Chinese civil law textbook that he translated, William Jones says ". . there is very clear support for the notion that China's industrialization will be achieved by permitting individuals to make contracts on their own and to organize collective entities-juristic persons or corporations-that will act independently and in accordance with the market. The function of the civil law is to further and pro- 
lated area, it may be possible to discern principles underlying the Economic Contract Law, which one observer has stated serves to "compile" concepts and principles that were previously scattered among various decrees that concerned the use of contracts to formalize economic relationships. ${ }^{150}$

We must obviously move from the rules themselves to analyzing application in practice of legal concepts intended to reorder the Chinese economy. Some areas for study are suggested by The General Principles of Civil Law, a partial civil code that was promulgated in 1986. For the first time since 1949, it gave formal legal status to the concept of the "legal person," which in practice could be both an active vehicle for private economic activity and an instrument for separating the state-owned enterprise from the administrative bureaucracy that supervises its activity. ${ }^{151}$ Now, study of the power and use of the concept in practice is needed. In tort law, the partially codified civil law expresses key concepts, and study of litigation should indicate whether principles of civil responsibility with a potentially extensive reach are presently evolving. ${ }^{152}$ In another obvious area of inquiry, research has suggested that the availability of lawyers and courts to enforce rights to claim damages for breach of contract has begun to stimulate the assertion of such rights. ${ }^{153}$

It should also be plain from what has been said earlier about the links between formal legal institutions and policy that inquiry must be pressed beyond them into the impact on legal practice of other government and Party organizations. The very novelty of Chinese legal institutions makes uncertain their place among other and longer-established institutions. The uncertainty is greater because of the extent and rapidity of social change during the last decade, especially in the countryside. Reform has already reconfigured many Chinese institutions, and the patterns of change are not uniform; reform has dramatized the existence not of one China, but many. For example, Vivienne Shue has noted that in one emergent pattern in the Chinese countryside, the local government acts as "competitor, investor, and entrepreneurial agent," while in another it is "coordinator, facilitator, and regulator." 154 Diverse institutional patterns of

tect this development. Whether this aim will be achieved is anyone's guess." "Editor's Introduction," in Basic Principles of Civil Law in China xvi (William C. Jones ed. 1989).

150. See, Potter, supra n. 84 at 31-72.

151. "General Principles of Civil Law," translated by Gray and Zheng, $34 \mathrm{Am} J$. Comp. L. 715 (1986).

152. See, Epstein, "The Evolution of China's General Principles of Civil Law," supra n. 52.

153. See Lester Ross, supra n. 85. See $n$. 193 infra for discussion of research into these matters flawed by the narrowness of the authors' inquiry and the limitations of their sources.

154. Vivienne Shue, "The Chinese State Thickens, Emerging Patterns of State- 
economic and governmental activity will affect and be affected differently by newly emergent legal rules and the concepts embedded in them.

To take the study deeper, the workings of Chinese legal institutions, especially with the social and political processes to which they are linked, could be better illuminated by clarifying the functions performed by the institutions. I recognize that this emphasis echoes an approach that has proven disappointing in the past. ${ }^{155}$ In studying foreign law, although comparatists have long suggested that cultural frontiers can be surmounted by seeking to understand the functions of legal institutions in contexts that transcend the formal legal realm, ${ }^{156}$ they have neither been able to define with much exactness the concept of function nor convincingly establish the objectivity that functionalism implies. ${ }^{157}$

Yet the concept of function seems useful if used with restraint. Almost twenty years ago, I wrote that

"it seems preferable to analyze legal and administrative practices and arrangements in terms of the functions they perform, recognizing that several functions may coexist, that apparently similar institutions may have different functions, and that apparently dissimilar institutions may perform similar functions. . .I am seeking here not an intel-

Society Relations in Rural China," Paper revised for presentation at the Center for Chinese Studies Spring Regional Seminar, University of California, Berkeley, April $7-8,1989$ at $20-1$.

155. A summary of recent challenges to functionalist thinking in American legal theory is Mark Kelman, A Guide to Critical Legal Studies 228-33 (1987) and sources there cited.

156. See, e.g., Mary Ann Glendon, Michael Wallace Gordon, and Christopher Osakwe, Comparative Legal Traditions: Texts, Materials and Cases 11-12 (1985) and authorities there cited.

157. For illustrative formulations of the level of generality at which leading comparatists have been content to formulate their functional outlook, see, e.g., H.C. Gutteridge, Comparative Law: An Introduction to the Comparative Method of Legal Study and Research 174 (2nd ed. 1949): "the laws must be examined in the light of their political, social or economic purpose, and regard must be paid to their dynamic rather than their static or doctrinal aspects"; Konrad Zweigert and Hein Kötz, Introduction to Comparative Law 11 (2nd rev. ed., translated by Tony Weir, 1987): "Comparative lawyers have long known that only rules which perform the same function and address the same real problem or conflict of interests can profitably be compared. They also know that they must cut themselves loose from their own doctrinal and juridical preconceptions and liberate themselves from their own cultural context in order to discover 'neutral' concepts with which to describe such problems or conflicts of interests." The authors further state that the comparatists must "force themselves to be sufficiently receptive to the non-legal forces which control conduct, and here they have much to learn from the more open-minded sociologists of law." Id. Absent from the discussions quoted is further consideration of the methodological problems so directly raised. Criticizing comparative functionalism, particularly that of Zweigert and Kötz, supra, is Frankenberg, "Critical Comparisons: Re-Thinking Comparative Law," 26 Harv. Int $\eta$ L. J. 411 at 434-40 (1985). 
lectual system but different modes of asking questions. . .It seems advisable to avoid preconceptions about legal institutions." 158

I am no more confident today than I was then about the possibility of attaining scholarly objectivity, and as a practicing lawyer in China I am even more aware today of the weight of the conceptual baggage that Westerners, especially lawyers, carry with them when they seek to understand contemporary China. Nonetheless, the search for function seems particularly useful in analyzing legal institutions that are recent legislative creations, because as they are put into practice differences inevitably appear between the functions that their creators intended to be primary and those which, unintended and unrecognized, appear in practice. ${ }^{159}$ The search for function may help to expose ambiguities about the purposes of newlycreated institutions, such as those that mark attempts to regularize the formal Chinese criminal process, both before ${ }^{160}$ and after reform. ${ }^{161}$

Trying to identify and analyze the functions of legal institutions is not inconsistent with the self-consciousness about assumptions that I have already urged. Functional analysis has been rightly criticized because it leads the researcher to "make assumptions about the way social systems function in terms of postulated needs which imply the way such systems should function."162 I am arguing for a far more restrained perspective here, one that "merely tries to analyze the relationship between particular closely defined social phenomena"163 in a search for what the great comparatist Ernst Rabel called the "social purpose" of legal institutions. ${ }^{164}$

Grounding the clarification of functions, intended or not, in the study of practice means that we must ask how these institutions are made to work by the officials who staff them, and how they may mesh or clash with other institutions that existed before the new

158. Lubman, supra n. 14 at 258. Similarly, Alford has suggested that we deepen our analysis of the "intended function and actual operation" of the traditional criminal justice process, of the social context in which it operated, and of the standards we use to evaluate the criminal justice system of a society "removed from our own both culturally and temporally." Alford, supra n. 98 at $1245,1248$.

159. The distinction intended here is that between manifest and latent functions, as defined in Robert K. Merton, Social Theory and Social Structure 51 (1957).

160. Lubman, supra n. 12 at 565-72.

161. Lubman, "Emerging Functions of Formal Legal Institutions in China's Modernization," supra n. 106.

162. Roger Cotterell, The Sociology of Law: An Introduction 99 (1984).

163. Id. (Emphasis in original.)

164. Association of American Law Schools, Summarized Proceedings of the Institute in Teaching of International and Comparative Law 111 (1948), quoted in Kaplan, "Civil Procedure-Reflection on the Comparison of Systems," 9 Buffalo $L$. Rev. 409 at 431 (1960). 
ones were created. In this connection, study of the impact of bureaucratic politics on the new formal legal institutions is essential.

The Chinese bureaucracy is characterized by a striking combination of cellularity and mutual interdependence. ${ }^{165}$ The introduction of new policies and institutions may disrupt long-standing previous commitments of personnel to particular organizations; administrative units are reluctant to take risks and resist attempts by other, new agencies to reduce their power. The creation of the new legal institutions brings to Chinese administration concepts of jurisdiction, procedural regularity and legal rights - all concepts alien to China's political culture. Since 1949 the Chinese style of implementing policy has been marked by interagency negotiation and consensusbuilding, often depending on personal associations and influence. ${ }^{166}$ In practice, policies of reform and rapid change have often clashed with long-established institutional patterns, and there is a long history of distortion at the local level of policies formulated at the center.

The formal criminal process is one obvious example of an arena of interagency contention. What, for example, do judges, procurators and police believe should be the rights of defendants under the Code of Criminal Procedure and the means of applying the Code in practice? During the 1960s, long before the Code was adopted, the agencies of the criminal process would negotiate among themselves about differences over procedural irregularities, and the police resented and retained power against the then-newly invigorated procuracy and courts that were intended to regularize the formal criminal process, ${ }^{167}$ and similar attitudes continue to exist today. ${ }^{168}$

But it is necessary to go further. I have described here the general direction of an effort to try to understand what the architects of the institutions hope to accomplish and how; the procedures used to make the institutions work; and the relationship among the results that the institutions are supposed to bring about, the way they work, and the results attained. Transcending and suffusing the formal legal realm are the symbols to which the legal institutions are sup-

165. On these characteristics of the Chinese bureaucracy as they affect policy implementation, see, e.g., Policy Implementation in Post-Mao China 11-17 (David M. Lampton ed. 1987), and references there cited; Kenneth Lieberthal and Michel Oksenberg, Policy Making In China: Leaders, Structures and Processes 160-167 (1988).

166. See Lampton, id. at 14-17.

167. See, e.g., Cohen, supra n. 12 at 36; IJubman, supra n. 12 at $563-4$.

168. See, e.g., an article in the police newspaper arguing that the police have coordinate power with that of the procuracy and courts in interpreting Chinese law, "Article Views Judicial Powers of Security Organs, Renmin Gongan Bao (People's Public Security Daily), 5 January 1990, in FBIS, Daily Report: China, Supplement 9 February 1990, 16. 
posed to give legitimacy, the ideologies that they support, and popular notions of what is right. This leads us in. a direction in which research should move, into Chinese society itself.

\section{B. Research on Chinese Law in Society}

It is helpful in fashioning an approach to research to be cautious about the concepts we will use - or not use. In framing research into the dynamics of Chinese legal institutions, it seems important to avoid very high levels of abstraction. Similar issues have troubled ethnography. Suggestions for a useful approach come from Clifford Geertz, who advocates "thick description" as the restrained level of conceptualization that it is appropriate to attempt in order to develop cross-cultural understanding. ${ }^{169} \mathrm{He}$ argues that the ethnographer uses "very general, made-in-the-academy-concepts and systems of concepts" with the aim of drawing "large conclusions from small, but very densely textured facts. . ."170 He argues for keeping "the analysis of symbolic forms as closely tied as possible to concrete social events and occasions. . . and to organize it in such a way that the connections between theoretical formulations and descriptive interpretations are unobscured by appeals to dark science."171

The foreign student of Chinese law is like Geertz' ethnographer, and Geertz' suggestion is apposite here: the foreign student must begin close to the perspective of the participants themselves, and when "deploying" his analytical concepts must keep them grounded in "thick description" of the specific details of the institutions under study. Although it is not possible to elaborate a detailed method here, a general orientation can be sketched. For one thing, the student of Chinese law, like the anthropologist or sociologist, must inquire into the values and expectations of participants in the activities of the institutions involved, and of the general populace. One aim should be to understand the legal culture that affects the use and operation of legal institutions. I use "legal culture" to mean, in the words of Lawrence Friedman, "those parts of the general culture - customs, opinions, ways of doing and thinking - that bend social forces toward or away from the law and in particular ways."172

169. "Thick Description: Toward an Interpretive Theory of Culture," Clifford Geertz, in The Interpretation of Cultures 3-30 (1973).

170. Id. at 28.

171. The relevance of this approach to comparative law is suggested by commentators who have described Geertz as saying that the anthropologist "chooses anything in a culture that strikes his attention and then fills in detail and descriptive elaboration so as to inform readers in his own culture about meanings in the culture being described." George E. Marcus and Michael J. Fischer, Anthropology as Cultural Critique: An Experimental Moment in the Human Sciences 29 (1986).

172. Lawrence M. Friedman, The Legal System: A Social Science Perspective 15 (1975). See also Alan Watson, Legal Transplants: An Approach to Comparative Law 
The reader does not have to be reminded at length about profound differences between traditional Chinese and Western attitudes toward law. Law, as a Chinese scholar has suggested, was "one of countless methods of governing, which could be used and constituted at will by the ruler". ${ }^{173}$ In dispute settlement widelyheld cultural values discouraged invocation of the authority of formal legal rules or of the agencies, judicial or otherwise, charged with formally enforcing and applying such rules. ${ }^{174}$ The values related to social harmony and conflict interacted with family and social structure and with political institutions to form a rich and disorderly assortment of forces that contributed to the makeup of Chinese "legal culture".

The concept of "legal culture" is imprecise and could arguably include any cultural practice or value which may affect perceptions of law-related institutions. But this breadth of approach is appropriate to a society like China's in which law is marked by an absence of techniques and reasoning different from those used in Chinese culture and life generally. ${ }^{175}$ Moreover, legal culture is neither readily knowable nor static. In contemporary China, for example, institutions for dispute settlement were created by economic reform, but will be shaped by the extensive social and economic changes that reform has unleashed in some parts of China.

In the Chinese countryside, for example, the evolution of institutions for settlement of commercial disputes will be affected by the distribution of power. Some foreign students have argued that although decollectivization of land has reduced the political power of rural cadres, the economic power of the cadres has grown as they become involved in commerce and industry. ${ }^{178}$ Research suggests that in the half-market, half-planned economy of today village cad-

(1974): "Ideally, a comparatist should be comparing not laws as such but the entire legal culture, i.e., the network of values and attitudes relating to law and practices".

173. Liang Zhiping, "Explicating 'Law': A Comparative Perspective of Chinese and Western Legal Culture," $3 J$. Chin. L. 55, 89 (1989).

174. A recent Chinese discussion by a Chinese scholar of this subject is Liang Zhiping, id.

175. See Lawrence Rosen, The Anthropology of Justice: Law as Culture in Islamic Society xiv (1989): "the analysis of legal systems, like the analysis of social systems, requires at its base an understanding of the categories of meaning by which participants themselves comprehend their experience and orient themselves toward one another in their everyday lives."

Rosen studied dispute settlement under Islamic law in Morocco by khadis, who have long been believed in Western jurisprudence to be the archetype of subjective and irrational judges since they were so styled by Max Weber. He found their decisions, however, to be grounded in and limited by widely accepted notions of propriety. Ideas and values widely held throughout the culture directly infused dispute settlement by the khadis, although specialized techniques and methods of reasoning were strikingly absent by contrast to Anglo-American courts.

176. See, e.g., Vivienne Shue, supra n. 154; Potter and Potter, supra n. 112 at 281. 
res have gained economic power over ordinary peasants that is translated into new patron-client ("clientelist") relationships, which in turn directly affect the application of legal rules. ${ }^{177}$ Such social and economic forces will necessarily shape rural dwellers' attitudes toward dispute settlement. The clientelist relationships could be expected to overshadow legal forms; at the same time, writers have suggested that settlement of disputes by courts is increasingly viewed by some Chinese as preferable to relying on personal relationships ${ }^{178}$ and as a desirable alternative to extra-judicial mediation, ${ }^{179}$ and one observer has discerned the effect on the outcome of particular disputes of popular notions of what is right and fair. ${ }^{180}$

Mediation, long seen by Chinese and foreigners alike as the preferred Chinese mode of dispute settlement, will reflect these socioeconomic currents. As noted earlier, not only does current policy stress the importance of extrajudicial mediation, but most of the civil disputes that are taken to the courts today are disposed of through mediation.181 In understanding Chinese legal culture and institutions, we will have to cease treating "mediation" as a unitary concept. It had no single style or form in traditional China, ${ }^{182}$ and even before reform mediation was a complex institution that promoted a variety of traditional and modern values that were not always mutually consistent. ${ }^{183}$ Today, styles of mediation and the values promoted by it are bound to vary, practiced as it is in settings as varied as urban neighborhood mediation committees, city offices for settling housing disputes, arbitration commissions for settling contract disputes, and the courts themselves. The status and power of mediators, particularly in the countryside, are also bound to affect the outcomes of disputes and perceptions of the process by both disputants and observers. ${ }^{184}$

Larger developmental processes not unique to the PRC will also mark dispute settlement. Economic growth in Taiwan made values associated with tradition become increasingly fragmented and manipulable in the settlement of disputes, ${ }^{185}$ and if private and collec-

177. Jean C. Oi, State and Peasant in Contemponary China: The Political Economy of Village Government 234 (1986).

178. " 'Relationships' bah: It's law that counts," China Daily, 28 Aug. 1986.

179. See Palmer, supra n. 86.

180. See Chang, supra n. 90 at $132-35$, discussing application of "a basic principle of fairness" by courts deciding contract disputes.

181. See text at $\mathrm{n} .90$ supra.

182. See, e.g., Martin Shapiro, Courts: A Comparative and Political Analysis 18591 (1981).

183. See, e.g., Lubman, supra n. 16.

184. See Potter and Potter, supra n. 112 at 296-312, discussing "a caste-like system of social stratification" in the countryside.

185. See Michael J. Moser, supra n. 8 at 184: "for individual disputants in search of vindication, revenge, self-gain or face [Confucian ideology] it constitutes a rich vo- 
tive economic activity grow in the PRC, similar fragmentation of values will occur there. Finally, an even broader perspective suggests that although mediation everywhere may profess to restore or establish social harmony, the "harmony ideologies" underlying mediation vary widely and must be clearly identified; ${ }^{186}$ so too, in China.

This survey of subjects for study and research emphases has moved from legal rules to broadly held cultural values but research must still stay grounded in observing law-related institutions and processes on a small scale. The section that follows below tries to knit loosely together my principal themes, by returning to a highly specific subject that illustrates some of the desirable emphases that have been discussed here.

\section{The Proposed Approach Illustrated: Concepts of Rights Revisited}

I return here to contemporary Chinese notions of rights, here private rights, which can be fruitfully studied using the concepts of function and legal culture that have been mentioned already. Some foreign scholars have speculated that despite the formidable influences of China's past which may inhibit the vindication of private rights by formal legal institutions, economic reforms could nourish the evolution of values that would support such institutions. ${ }^{187}$ One of these is a new consciousness of rights, and the research strategy that I have argued for here may be illustrated by one study of some of the issues related to rights-consciousness. In Zweig, Hartford, Feinerman and Deng, "Law, Contracts and Economic Modernization: Lessons from the Recent Chinese Rural Reforms,"188 the authors studied formal legal institutions in the settlement of disputes arising out of commercial contracts such as those involving sales of commodities by groups of peasants to state agencies.

cabulary of shared symbols by which private action may be justified in the public arena."

186. See Laura Nader, Harmony Ideology: Justice and Control in a Zapotec Mountain Village, esp. at 291-322 (1990).

187. Potter, supra n. 134 at 623; Edwards, supra, n. 132 at 75. See Nathan, supra n. 135 at 230-31: "Some activists (and foreigners) now hope that the development of the economy will cause a kind of natural political evolution - that the government will loosen its control of the economy, accommodate more and more ideas from the West, and yield to the demands for freedom of a rising technical and managerial class. Judging from the experience of the developed socialist economies of Europe, such economically induced change may include greater legal protection for individuals, enhanced intellectual and cultural tolerance, and a consultative style of decisionmaking - the types of evolution that are in fact occurring in Deng's China."

188. Zweig, Hartford, Feinerman, and Deng, "Law, Contracts, and Economic Modernization: Lessons from the Recent Chinese Rural Reforms," 23 Stan. J. Int $l L$. 319 (1987). 
Relying on a written discussion of six cases that had been summarized in a document for internal circulation among officials in a rural county, the authors found that some of the recently revived legal institutions - notarial agencies, lawyers and courts - were involved in the resolution of these disputes. Some of the contracts had been notarized at state notarial agencies; when contract disputes occurred, some of the peasants involved had consulted lawyers; and some of the disputes were settled by the courts. Although judicial involvement sometimes led to compromise settlements through mediation rather than formal adjudication by judges, they nonetheless upheld what were explicitly labeled as contractual rights of the litigants. The authors emphasize the instrumental use of legal institutions, which were being used to uphold rural contracts because current CCP policy supported the increased use of contracts. This unstable basis of support for legality inspires skepticism about the future of the autonomy of Chinese law. At the same time, however, the courts, by continuing to uphold the rights of peasants under their contracts, could reduce the power of cadres over peasants.

The authors' sources of information were very limited, and there is some evidence that the role of the legal institutions they studied in carrying out CCP policy is not clearly differentiated from other bureaucratic agencies and from CCP officials. Thus, newspaper articles have reported the activities of CCP secretaries, rather than courts, in preventing and undoing unilateral breaches of contracts with peasants. ${ }^{189}$ Also, as already stated above, considerable evidence suggests that economic reform has not dislodged the power of rural cadres, who have used their positions to extend their influence and control, not only over agricultural activities, but over the industry that has burgeoned in the countryside as a result of reform. ${ }^{190}$

The authors' comparative perspective is unclear. Commenting that peasants' conceptions of their rights under contracts are tempered by traditional preferences for mediation and compromise, they do not articulate a Western analogue with which to compare the Chinese concepts of rights which they find weaker. There is, of course, much literature that suggests that Americans are less litigious than often supposed. ${ }^{191}$

In addition, the authors do not speculate that Chinese notions of

189. "Henan's Liu Jie handles case of broken contract," FBIS, Daily Report: China, 23 Mar. 1984, P-1.

190. Suggesting the involuntariness of many contracts, see Oi, supra n. 177 at 178 81 (grain procurement contracts), 193-194 (other rural contracts).

191. See, e.g., Macaulay, "Non-contractual Relations in Business: A Preliminary Study," reprinted in Law and the Behavional Sciences (Lawrence M. Friedman and Stewart Macaulay eds. 1977) 141-158. 
rights could be more fluid than those of the Western counterparts to which they are (only implicitly) compared, and they may be comparing Western theory with Chinese practice. Chinese claimants may expect less than American litigants when they assert that their "rights" have been violated. Even notions of right that are diluted by comparison to Western ideal types could, however, still be useful - and perceived by Chinese peasants as being useful - in bringing about results considered to be "just" or "fair" in a Chinese context.

My concern here, however, is not the authors' conclusions but the aptness of their questions. They have studied Chinese law in Chinese society rather than Chinese law as a collection of formal rules; by incorporating into their research speculation about the impact of legal institutions on power relationships in the Chinese countryside, they have used the study of Chinese law to add insight to the study of Chinese society.

\section{Concluding Comments}

Although the research orientation that I have urged here may seem obvious to many, my concerns are underscored by recent signs of great insensitivity to the problems discussed here, including publication of an entire casebook that is a monument to flawed methodol$\mathrm{ogy}^{192}$ and an article on dispute resolution that relies principally on Chinese law professors' idealized visions of the Chinese legal system. ${ }^{193}$ Moreover, although I have written this article as a student

192. See Law in the People's Republic of China (Ralph M. Folsom and John H. Minan eds. 1989) a survey of Chinese law. A reviewer describes its treatment of pre1949 China as "superficial and, in places, almost embarrassing," Berring, $38 \mathrm{Am}$. J. Comp. L. 395, 397 (1990) and criticizes it for ignoring the legal history of the PRC before reform, failing to discuss the role of the CCP meaningfully, and failing to distinguish between the language of Chinese enactments and law in practice.

193. See Spanogle and Baranski, "Chinese Commercial Dispute Resolution Methods: The State Commercial and Industrial Administration Bureau," $35 \mathrm{Am}$. J. Comp. L. 761 (1987).

The authors describe the resolution of disputes arising out of contracts between state enterprises. Before 1979, they state, such disputes would be solved by an "administered" solution in which fault was irrelevant and no damages were awarded; arrangements for alternative allocations of resources that might be necessitated by a breach of contract turned on personal ties in the bureaucracy. They describe dispute resolution since 1979 as predominantly governed by market forces: defective or late performance has become a legal issue involving fault, which is decided in arbitration proceedings conducted by the State Administration of Industry and Commerce ("SAIC"). The SAIC is characterized as having a "tradition of relative neutrality" and as functioning as "more of a 'neutral' arbitral body" (at 783). The authors conclude that arbitration is beginning "to exhibit characteristics of the judicial process rather than the informal management/administrative process" (at 797). The authors fail to state their assumptions about what is "administered", "judicial", and "neutral", among other concepts which they use as if their content was objectively verifiable. An even more basic problem is that the authors have idealized the system of dispute resolution they describe. They have clearly relied almost completely on promulgated Chinese rules and on extensive conversations with Chinese law profes- 
of Chinese law, my own experiences as a practicing lawyer in China for almost twenty years reinforce the views I have expressed here. In negotiations and in disputes I encounter again and again the influence of political and cultural forces mentioned here such as confusion of law and policy, bureaucratic mentalities hostile to limitation by law, and cultural aversion to formal dispute settlement. At the same time, I have also met officials and legal scholars - and many ordinary Chinese citizens - who articulate consciousness of rights that is entirely consistent with Western notions of the rule of law.

Efforts to understand the forces that influence legal institutions should complement other efforts to understand Chinese society. The research done by American social scientists on China suggests that they do not appear to read much of what is written on Chinese law. ${ }^{194}$ Looking back on American perceptions of China since Americans resumed traveling there again in 1972, it seems clear that if earlier writings on Chinese law had been more widely read by scholars and visitors, some illusions about China's political development might not have arisen. We might recall that some saw in China a participatory and populist society ${ }^{195}$ and an enlightened legal system that reduced litigation ${ }^{196}$ and offered insight into hu-

sors and legal specialists. Unfortunately, the system they describe is one that Chinese law professors would like to see instituted, but is apparently very different from the system in operation that is extensively discussed in economic literature which the authors have totally ignored. See, e.g., Byrd and Tidrick, "Factor Allocation and Enterprise Incentives in China's Industrial Reform," in China's Industrial Reform 60 (Gene Tidrick and Jiyuan Chen eds. 1987); more decisive for enterprise profits than any consequences of the economic reforms is bureaucratic bargaining by managers with their superiors on the taxes that will be paid by their enterprises and on allocations of raw materials and other inputs. See, e.g., Walder, "Factory and Manager in an Era of Reform," China Quart., June 1989 at 242. See also Gipoloux, "Industrial Restructuring and Autonomy of Enterprises in China: Is Reform Possible?", in II Transforming China's Economy in the Eighties (Stephan Feuchtwang, Athar Hussain, and Thierry Pairault eds., 1988) 106 at 110: (". . there is practically no recourse in the event of incomplete or delayed deliveries").

194. For example, without meaning to single him out for invidious comparison one scholar's excellent recent discussion of reform, Harry Harding, China's Second Revolution: Reform After Mao (1987), only mentions law twice in the index. Notable exceptions to the social scientists who have generally ignored law are Goodman, "Democracy, Interest and Virtue: The Search for Legitimacy in the People's Republic of China," in Foundations and Limits of State Power in China 291 (Stuart R. Schram ed. 1987), (law used to legitimize CCP rule), and Richard Baum, "Modernization and Legal Reform in Post-Mao China: The Rebirth of Socialist Legality," XIX Studies in Comparative Communism 69 (Summer 1986), (examining "legalism" in Chinese reform and noting the continued dependence of the rule of law in China on CCP self-restraint).

195. See, e.g., James P. Brady, Justice and Politics in People's China: Legal Order or Continuing Revolution? (1982), and the survey by Harry Harding, "From China, With Disdain: New Trends in the Study of China," supra n. 143 at 937-938.

196. See, e.g., a report that then-Chief Justice Warren Burger, during a visit to China, "praised China for settling civil disputes through mediation." "U.S. Chief 
mane reform of criminals; ${ }^{197}$ after reform began, some assumed that fundamental political characteristics of the Chinese system would be quickly transformed.198 The sophistication of observers who expressed such views would have benefited from the insights of American research on Chinese law into the depth of politicized CCP control over Chinese society.

More important than the relevance to Chinese studies before reform of studying Chinese law, however, is its relationship to understanding forces that are at work today shaping China. The control of the party-state has begun to erode, and what one scholar has called zones of conduct to which state and Party are indifferent have begun to appear ${ }^{199}$ such as private and collective economic activity. Will legal institutions be used to protect that "indifference"? A student of Chinese politics has written that

“. . . in Chinese politics, the two traditional limitations on power, law and custom, are missing. And the prospect is that power is likely to become even more important because the rather fragile Communist form of restraint, that of ideology, will probably erode faster than a system of law can be established."200

The new legal institutions have been created to fill interstices left by the partial receding of totalitarian power that has marked reform. The study of Chinese law today inquires into nothing less important than whether Chinese state and Chinese society will be knitted together differently than they have been before.

China will long be an intractable object of study. Chinese bureaucrats, including legal officials, are likely to remain averse to close study by foreigners of their work in practice, and the linguistic and cultural gaps that separate Chinese society from its would-be observers cannot be erased. But the decade of reform began processes of change that made China relatively more open to the view of foreign students than it had been before, and there is no sign that it will soon close.

Justice in Shanghai," New China News Agency, 8 September 1981 in British Broadcasting Corporation, Summary of World Broadcasts, September 10, 1981, FE/6824/ A1/1.

197. See, e.g., the report that Chief Justice Burger "said that China's system of transforming criminals by combining punishment with education was the best he had ever seen." "US Chief Justice in Shanghai," id.

198. See, e.g., Time, Jan 6, 1986, p. 32 noting that although Deng Xiaoping did not intend to allow China to become anything other than a one-party dictatorship, the Constitution of 1982 "marked a step toward making China a society governed by law rather than the whim of party officials". Alford, supra n. 75 argues that many foreign specialists on China law were overly optimistic about the accomplishments of Chinese law reform.

199. Baum, supra n. 194 at 102.

200. Lucian Pye, The Dynamics of Chinese Politics 128 (1981). 
The legitimacy and authority of the Chinese Communist Party were severely impaired in mid-1989, and the abrupt bloody end of Beijing's bright spring did not make irrelevant the law reform efforts of the previous decade. The events of June, 1989 moved issues of legal development closer to the center of Chinese politics than ever before. Regardless of the configuration of institutions that will wield power in Beijing and elsewhere in China, in the first decade of reform Chinese legal institutions had assumed a new importance. They have established a presence; whether they can become a permanent force is among the questions that must await answer by China, under the eyes of students of China. 
HeinOnline -- 39 Am. J. Comp. L. 3421991 